\title{
Recent Catalytic Advances in Hydrotreatment Processes of Pyrolysis Bio-Oil
}

\author{
Giuseppe Bagnato $^{1}(\mathbb{D})$, Aimaro Sanna ${ }^{2}$, Emilia Paone ${ }^{3, *(\mathbb{D})}$ and Enrico Catizzone $^{4(\mathbb{D})}$ \\ 1 School of Chemistry and Chemical Engineering, Queen's University Belfast, David Keir Building, \\ 39-123 Stranmillis Rd, Belfast BT9 5AG, UK; G.Bagnato@qub.ac.uk \\ 2 Advanced Biofuels Lab, Institute of Mechanical, Process and Energy Engineering, School of Engineering \& \\ Physical Sciences, Heriot-Watt University, Edinburgh EH14 4AS, UK; A.Sanna@hw.ac.uk \\ 3 Dipartimento di Ingegneria Industriale (DIEF), Università degli Studi di Firenze, Via di S. Marta 3, \\ I-50139 Firenze, Italy \\ 4 ENEA-Italian National Agency for New Technologies, Energy and Sustainable Economic Development, \\ Research Centre of Trisaia, I-75026 Rotondella, Italy; enrico.catizzone@enea.it \\ * Correspondence: emilia.paone@unifi.it; Tel.: +39-096-5169-2278
}

Citation: Bagnato, G.; Sanna, A.; Paone, E.; Catizzone, E. Recent Catalytic Advances in Hydrotreatment Processes of Pyrolysis Bio-Oil. Catalysts 2021, 11, 157. https://doi.org/10.3390/ catal11020157

Received: 28 December 2020

Accepted: 21 January 2021

Published: 23 January 2021

Publisher's Note: MDPI stays neutral with regard to jurisdictional claims in published maps and institutional affiliations.

Copyright: (c) 2021 by the authors. Licensee MDPI, Basel, Switzerland. This article is an open access article distributed under the terms and conditions of the Creative Commons Attribution (CC BY) license (https:/ / creativecommons.org/licenses/by/ $4.0 /)$.

\begin{abstract}
Catalytic hydrotreatment (HT) is one of the most important refining steps in the actual petroleum-based refineries for the production of fuels and chemicals, and it will play also a crucial role for the development of biomass-based refineries. In fact, the utilization of HT processes for the upgrading of biomass and/or lignocellulosic residues aimed to the production of synthetic fuels and chemical intermediates represents a reliable strategy to reduce both carbon dioxide emissions and fossil fuels dependence. At this regard, the catalytic hydrotreatment of oils obtained from either thermochemical (e.g., pyrolysis) or physical (e.g., vegetable seeds pressing) processes allows to convert biomass-derived oils into a biofuel with properties very similar to conventional ones (so-called drop-in biofuels). Similarly, catalytic hydro-processing also may have a key role in the valorization of other biorefinery streams, such as lignocellulose, for the production of high-added value chemicals. This review is focused on recent hydrotreatment developments aimed to stabilizing the pyrolytic oil from biomasses. A particular emphasis is devoted on the catalyst formulation, reaction pathways, and technologies.
\end{abstract}

Keywords: pyrolysis oils; catalytic hydrotreatment; heterogeneous catalysis; hydrogenation; biorefinery; green chemistry

\section{Introduction}

In a green and sustainable perspective, the world is moving from a strong fossil fuels' dependence to a consistent use of renewable feedstocks. In this view, Anastas and Green proposed in 1998 "the 12 principles of green chemistry" [1], where a particular attention was also given to (second and third generation) transportation biofuels, chemicals, commodities, and pharmaceuticals directly produced from biomass in modern biorefineries [2-6]. This transition is given not only by the matured awareness that fossil resources are running out, but it is mostly accelerated by the United Nation decision to adopt the 2030 Agenda for Sustainable Development, a program action of 17 ambitious goals (SDGs) and 169 targets aimed to eradicate the poverty, to protect the planet, and to ensure the prosperity for all [7]. Biomasses, that currently supply about $80 \%$ of global renewable energy and a low-emissions character, represent a unique sustainable pathway to successfully address SDGs $[1,7,8]$. Among several technologies that can use biomass waste as the feedstock to produce energy fuels, power, heat, and various high value-added chemicals [9-14], an interesting example is the use of lignocellulose (plant based biomasses mainly composed of cellulose, hemicellulose, and lignin) and microalgae (biomasses with high protein and carbohydrate content characterized by the absence of lignin) for the production of bio-oil 
that can be used as intermediate for the production of liquid bio-fuels [15]. Bio-oil is a dark brown-red colored liquid, with a characteristic smell of smoke and a chemical composition strictly related to the biomass feedstocks containing a wide number of unique compounds generated from the rapid quenching of pyrolytic fragments of lignocellulose [16]. Figure 1 shows the main compounds present in the bio-oil: an aqueous solution of several products derived from the fragmentation of cellulose and hemicellulose and from the depolymerization of lignin. The mixture consists of various organic compounds (20-30 wt $\%)$, water (19-20 wt\%), water-soluble oligomers (WS, also known as pyrolityc humin), and waterinsoluble oligomers (WIS, also known as pyrolityc lignin) (43-59 wt\%) that can be efficiently used for several applications, such as drop-in fuel, production of chemicals, and various carbon-based materials [17-22].

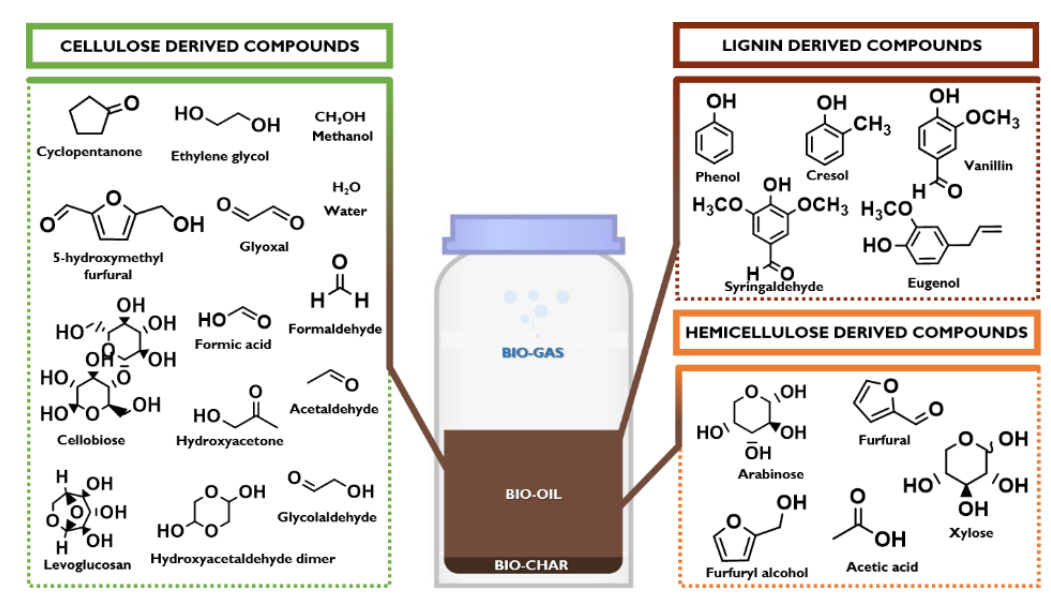

Figure 1. A simplified chemical composition of bio-oil: main lignocellulose-derived compounds.

Conventionally, bio-oil is produced by using a high energy demanding multistep process, such as pyrolysis (fast or slow, thermal or thermo-catalytic) and hydrothermal liquefaction (HTL). These thermochemical processes are conducted in the absence of oxygen and at high reaction temperature with the aim to allow the decomposition/depolymerisation of lignocellulose and microalgae into a bio-oil liquid (the major product), solid (bio-char), and gaseous products $\left(\mathrm{CO}_{2}, \mathrm{CO}, \mathrm{CH}_{4}, \mathrm{H}_{2}\right)$ (bio-syngas $[15,23,24]$. Bio-char can access applications in several fields (e.g., soil amendment in agriculture, chemical sensing, adsorbent material in wastewater remediation) or combusted to recover energy for the pyrolysis stage [25], while bio-syngas may be directly utilized for many energy uses (e.g., electricity generation, fuel for transport, cooking fuel, feedstock for fuel cells) [26]. HTL processes were developed to improve the efficiency of direct thermal decomposition methods and differ from the pyrolysis for the adoption of lower reaction temperatures and for the presence of a homogeneous or heterogeneous catalyst by applying water and simple aliphatic (e.g., methanol, ethanol, and 2-propanol) alcohols used as such or in combination as reaction solvents. However, bio-oils arising from these two processes cannot be directly used as drop-in fuels in conventional engines due to problems related to the presence of a common limiting feature, the high oxygen content of biomass otherwise responsible of chemical unfavorable properties of bio-oil (high acidity, high viscosity, thermal and chemical instability) [16].

Thus, a biorefinery process in which biomass is first converted in bio-oil by pyrolytic or HTL step followed by an oxygen removal stage represents a most promising approach for the production of biofuels and chemicals.

To this regard, in order to mitigate the oxygen content and to improve the bio-oil properties for practical use, some catalytic approach (catalytic cracking, hydrodeoxygenation HDO, etc.), based on a thermal-catalytic treatment of biomass (hydrotreatment or hydrotreating process), come to help. Among them, one of the most promising strategies 
is the catalytic hydrodeoxygenation (HDO) that allows the reduction of oxygen content providing, at the same time, the highest $\mathrm{C}$-atom efficiency.

Although this process allows to obtain bio-oil in a high yield, the formation of a variable quantity of coke remains a problem to be solved. In this context, it was reported that the presence of a suitable catalyst in a two-step biorefinery process can reduce the formation of coke by improving, at the same time, the bio-oil properties $[27,28]$. The first step (or stabilization step) permits the transformation of carbonyl and carboxyl functional groups into alcohols promoted by noble metals catalysts $(\mathrm{Pt}, \mathrm{Ru}$, and $\mathrm{Pd})$ in a temperature range between 100 and $300^{\circ} \mathrm{C}$. The second step is conducted between 350 and $400{ }^{\circ} \mathrm{C}$ and is driven by sulphide conventional catalysts that allows to completely remove oxygen species.

This review aims to provide a brief overview on recent advances in the catalytic hydrogenation process of bio-oil arising from thermal treatment of lignocellulosic biomass and microalgae, highlighting progresses made in terms of enhancing catalyst efficient activity for upgrade bio-oil HDO.

\section{Bio-Oil Proprieties}

Bio-oil is the main product of biomass pyrolysis. Historical documents report that this process was already used in ancient Egypt to prepare sealants for boats and ointments. In the 18th century, wood distillation provided compounds such as soluble tar, pitch, creosote oil, as well as chemical and non-condensable gases. Interest in biomass pyrolysis was revived in the 1980s, when the process was perfected to have a high yield of liquid compound [29]. The pyrolysis process carried out with a temperature between $400{ }^{\circ} \mathrm{C}$ and $600{ }^{\circ} \mathrm{C}$ and varying the residence time and heating rate, the product distribution changes. To maximize the process in term of liquid yield, the fast pyrolysis at $\sim 500{ }^{\circ} \mathrm{C}$ is usually preferred, advantageously producing a liquid yield up to three times larger than the conventional and slow pyrolysis [30].

As an example, Figure 2 shows the flow diagram of the BTG Bi-oliquids BV pyrolysis plant [31]. The first part of the plant consists in a drying unit where biomass from different origin (for example, wood, rice husk, bagasse, sludge, tobacco, energy crops, palm-oil residues, straw, olive stone residues, chicken manure) is dried to decrease the water content. The dry biomass, in presence of a hot carrier (sand), is then converted in a fluidized bed reactor into pyrolysis oil, gas, and char. After that, the products and the sand are separated from the vapor/gas phase by a series of cyclones. Then, the char and sand fraction is moved to a fluid bed combustor, where the char is used to heat the sand recycled in the fluidized bed. The vapor/gas phase is instead quenched by re-circulated oil to divide the bio-oil from the incondensable gases, where the latter are captured as high-pressure steam and utilized in a steam turbine system.

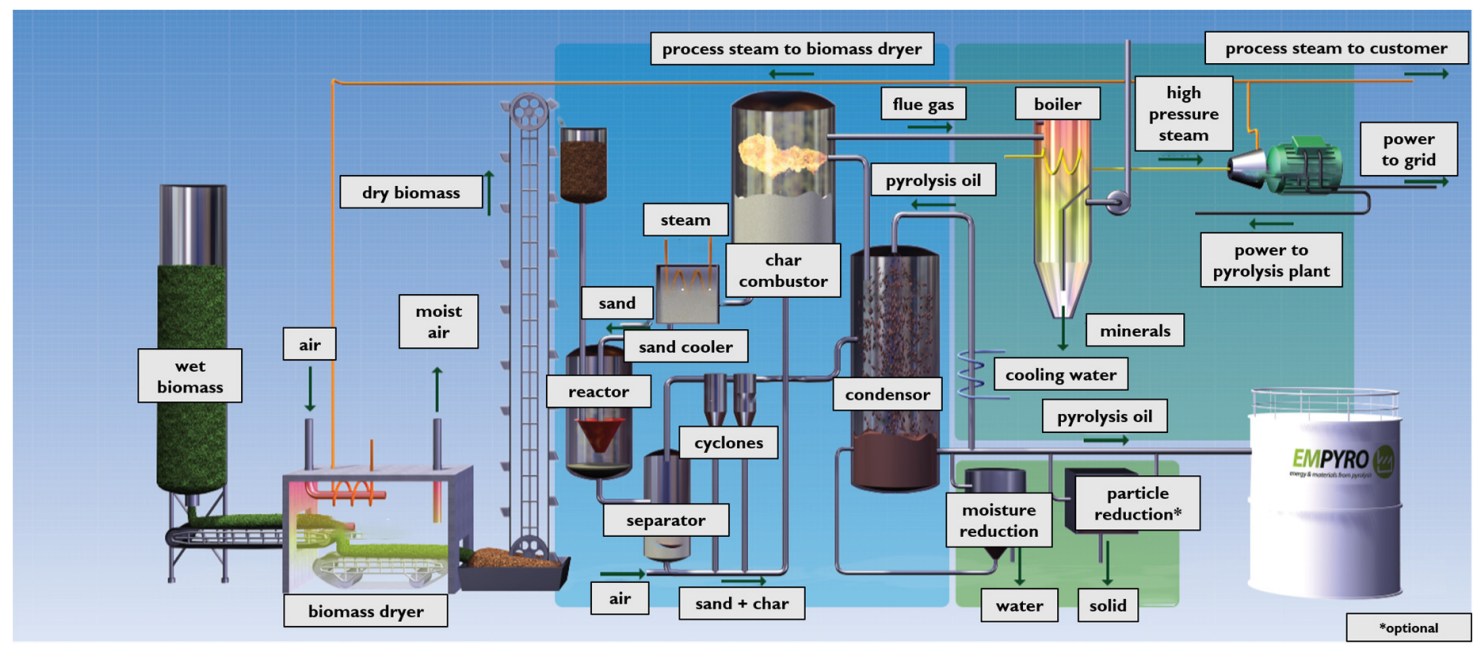

Figure 2. Pyrolysis plant. With permission from BTG Bioliquids BTG bioliquids BV [31]. 
Furthermore, recent researchers are focusing their attention to microalgae as feedstock for fast pyrolytic reaction [32]. Microalgae are classified as third-generation biofuel due to their fast growth cycle and high lipid content $(\sim 50 \%)$, easily converted in fuels. Moreover, microalgae do not require arable land and are adaptable at different water sources, including wastewater. The pyrolysis of microalgae is usually carried out in presence of a catalyst, such as zeolites, aluminosilicates, transitional metal-loaded zeolites, MOFs, silica gel [33-35]. The pyrolysis process for microalgae may be performed as (i) one-pot step process, where microalgae and catalyst are mixed together (ii) or a double-step process, the pyrolysis vapors from microalgae are swept over a catalyst at a specific temperature $[36,37]$.

The fast pyrolysis of biomass produces hundreds of different compounds (Table 1), where their composition depends of the cellulose, hemicellulose, lignin, and extractive content in the respective feedstock. The influence of biomass composition on bio-oils composition can be appreciated from the variability of the bio-oils elemental composition reported in Table 2, where the C content can vary from 39\% (pine sawdust) to about $60 \%$ (beech wood) under the same pyrolysis conditions. Furthermore, the operating conditions of the fast pyrolysis influence the bio-oil composition [38-40].

Table 1. Bio-oil composition.

\begin{tabular}{|c|c|c|c|c|}
\hline Fraction/Chemical Groups & Compound Types & $\begin{array}{c}\mathbf{w t} \% \\
\text { (Wet Basis) } \\
{[38]}\end{array}$ & $\begin{array}{c}\text { wt } \% \\
\text { (Wet Basis) } \\
{[39]}\end{array}$ & $\mathbf{w t} \%$ [40] \\
\hline \multicolumn{5}{|c|}{ Water solubles $75-85 \%$} \\
\hline Acids alcohols & Small acids, small alcohols & $5-10$ & 6.5 & 8.5 \\
\hline Ether-solubles & $\begin{array}{l}\text { Catechols, syringols, guaiacols, aldehydes, } \\
\text { ketones, furans, and pyrans }\end{array}$ & $5-15$ & 15.4 & 20.3 \\
\hline Ether-insolubles & Sugars & $30-40$ & 34.4 & 45.3 \\
\hline Water & Water & $20-30$ & 23.9 & - \\
\hline \multicolumn{5}{|c|}{ Water insoluble $15-25 \%$} \\
\hline Hexane-solubles & $\begin{array}{l}\text { Extractives (High MW compounds with } \\
\text { functional groups such as acids, alcohols) }\end{array}$ & $2-6$ & 4.35 & 5.7 \\
\hline DCM solubles & $\begin{array}{l}\text { Stilbenes, Low MW lignin degraded } \\
\text { compounds }\end{array}$ & $5-10$ & 13.4 & 17.7 \\
\hline DCM insolubles & High MW lignin degraded compounds & $2-10$ & 1.95 & 2.6 \\
\hline
\end{tabular}

Table 2. Feedstock composition updated from [35].

\begin{tabular}{ccccccc}
\hline Feedstock for Bio-Oil & $\mathbf{C}$ & $\mathbf{H}$ & $\mathbf{O}$ & $\mathbf{N}$ & $\mathbf{S}$ & Ref. \\
\hline Beechwood & 51.1 & 7.3 & 41.6 & & & {$[41]$} \\
Pine wood & 40.1 & 7.6 & 52.1 & 0.1 & & {$[42]$} \\
Rice husk & 39.92 & 8.15 & 51.29 & 0.61 & 0.03 & {$[43]$} \\
Beech wood & 58.6 & 6.2 & 35.2 & & & {$[44]$} \\
Pine sawdust & 38.8 & 7.7 & 53.4 & 0.09 & 0.02 & {$[45]$} \\
Eucalyptus & 44.8 & 7.2 & 48.1 & 0.2 & & {$[46]$} \\
White spruce & 49.6 & 6.4 & 43.1 & 0.2 & & {$[47]$} \\
Poplar & 49.5 & 6.05 & 44.4 & 0.07 & & {$[47]$} \\
Sawdust & 60.4 & 6.9 & 31.8 & 0.9 & & {$[48]$} \\
Microalgae & 54.8 & 7.6 & 28.7 & 8.5 & 0.4 & {$[49]$} \\
Scenedesmus & 44.6 & 6.1 & 40.8 & 4.8 & 3.6 & {$[50]$} \\
Nannochloropsis gaditana & 40.3 & 5.97 & 14.5 & 6.3 & 0.37 & {$[51]$} \\
Chlorella protothecoides & 62.1 & 8.7 & 11.2 & 9.7 & $\mathrm{n} / \mathrm{a}$ & {$[52]$} \\
Spirulina & 67.5 & 9.8 & 11.3 & 10.7 & $\mathrm{n} / \mathrm{a}$ & {$[53]$} \\
Nannochloropsis sp. & 80.2 & 6.2 & 5.8 & 6.2 & $\mathrm{n} / \mathrm{a}$ & {$[54]$} \\
\hline
\end{tabular}




\section{Catalytic Hydrogenation of BIO-Oil}

In refineries, the hydrogenation reactions are common operations to limit the presence of oxygen, nitrogen, sulphur, olefins, and aromatics. The reaction is generally catalyzed by molybdenum together with $\mathrm{Ni}$ or Co supported by $\gamma \mathrm{Al}_{2} \mathrm{O}_{3}$. The operating conditions depend on the type of feed: LHSV 0.2 to $8.0, \mathrm{H}_{2}$ circulation from 50 to $675 \mathrm{Nm}^{3} / \mathrm{m}^{3}, \mathrm{H}_{2}$ pressure between 14 and 138 bar, and temperatures between 290 and $470{ }^{\circ} \mathrm{C}$ [55]. Actually, there are not industrial processes for $\mathrm{HDO}$ of bio-oil, but several catalysts have been tested from noble metals to $\mathrm{Ni}$ and $\mathrm{Co}$, in presence of acid supports such as $\mathrm{Al}_{2} \mathrm{O}_{3}$ and $\mathrm{SiO}_{2}$, or $\mathrm{C}$, in the temperature range $150-500{ }^{\circ} \mathrm{C}$, pressure range between 2 and 200 bar [47]. In this section, recent advances on catalysts for HDO of bio-oil are summarized. Furthermore, technical aspects of emergent technologies (e.g., membrane reactors) for hydroprocessing are also discussed.

\subsection{Catalysts}

Hydro-processing is conventionally catalyzed in presence of metals from group VIII, such as nickel, palladium, and platinum [56]. Furthermore, group VIB metals (tungsten and molybdenum) have also been used for oxygen removal, since they are resistant to attack by oxygen, acids, and alkalis [57,58]. According to Masel [59], hydrogen is reactive in the surfaces of $\mathrm{Co}, \mathrm{Ni}, \mathrm{Ru}, \mathrm{Rh}, \mathrm{Pd}, \mathrm{Os}$, Ir, Pt as well as on $\mathrm{Sc}, \mathrm{Ti}, \mathrm{V}, \mathrm{Y}, \mathrm{Zr}, \mathrm{Nb}, \mathrm{Mo}, \mathrm{La}, \mathrm{Hf}$, $\mathrm{Ta}, \mathrm{W}, \mathrm{Cr}, \mathrm{Mn}, \mathrm{Fe}, \mathrm{Tc}$, and Re. A slower uptake of hydrogen was observed with $\mathrm{Cu}$ [59]. Some authors increased the catalyst activity adding a second metal in order to promote an efficient adsorption of hydrogen at low temperature $[60,61]$. The most used supports were alumina-silica, carbon, titania (rutile), and zirconia (monoclinic form). Activated carbon is a well-known high-surface area (typically $\sim 1000 \mathrm{~m}^{2} / \mathrm{g}$ ) support material, which has been shown to be stable in hot water processing environments; rutile titania and monoclinic zirconia have lesser surface area (typically $30-80 \mathrm{~m}^{2} / \mathrm{g}$ ) but have also demonstrated their utility as catalytic metal support and have been used in the hot water processing environment [62-64]. A possible pathway for upgrading bio-oils is represented by hydrogenation reactions in liquid phase, with the conversion of aldehydes, ketones, sugars, phenols, etc., in more stable alcohols. In order to improve the conversion of the bio-oils compounds and enhance the selectivity on desired products, several catalysts have been studied (Table 3). Interesting is the work of Wei et al. [65], where Pt over different ceria-zirconia supports were evaluated for the hydrogenation of cinnamaldehyde at 10 bar and $60^{\circ} \mathrm{C}$, obtaining a conversion in the range of $60-95 \%$.

Table 3. Hydrogenation reaction.

\begin{tabular}{|c|c|c|c|c|c|c|c|}
\hline Catalyst & Reactant & $\begin{array}{l}\text { Pressure } \\
\text { (bar) }\end{array}$ & $\begin{array}{c}\text { Temperature } \\
\left({ }^{\circ} \mathrm{C}\right)\end{array}$ & Time (h) & $\begin{array}{c}\text { Conversion } \\
(\%)\end{array}$ & Note & Ref. \\
\hline $30 \% \mathrm{Ni} / \mathrm{CNT}$ & acetic acid & 40 & 150 & 4 & 5.8 & $2 \mathrm{wt} \%$ cat & [66] \\
\hline $30 \% \mathrm{Cu} / \mathrm{CNT}$ & acetic acid & 40 & 150 & 4 & 3.5 & $2 \mathrm{wt} \%$ cat & [66] \\
\hline $\mathrm{Ru} / \mathrm{C}$ & acetic acid & 40 & 150 & 4 & 4.7 & $2 \mathrm{wt} \%$ cat & [66] \\
\hline $20 \% \mathrm{Mo} / \mathrm{CNT}$ & acetic acid & 40 & 150 & 4 & $<2$ & $2 \mathrm{wt} \%$ cat & [66] \\
\hline $\begin{array}{l}10 / 10 w t \% \\
\text { NiMo/CNT }\end{array}$ & acetic acid & 40 & 150 & 4 & 14.8 & $2 \mathrm{wt} \%$ cat & [66] \\
\hline $3 \mathrm{wt} \% \mathrm{Ru} / \mathrm{TiO}_{2}$ & acetic acid & 62 & 120 & $33 *$ & 37.5 & * time on stream & [67] \\
\hline $3 \mathrm{wt} \% \mathrm{Ru} / \mathrm{TiO}_{2}$ & Acetol & 62 & 70 & $14^{*}$ & 93.6 & * time on stream & [67] \\
\hline
\end{tabular}


Table 3. Cont.

\begin{tabular}{|c|c|c|c|c|c|c|c|}
\hline Catalyst & Reactant & $\begin{array}{l}\text { Pressure } \\
\text { (bar) }\end{array}$ & $\begin{array}{c}\text { Temperature } \\
\left({ }^{\circ} \mathrm{C}\right)\end{array}$ & Time (h) & $\begin{array}{l}\text { Conversion } \\
(\%)\end{array}$ & Note & Ref. \\
\hline $3 \mathrm{wt} \% \mathrm{Ru} / \mathrm{TiO}_{2}$ & Bio-oil & 62 & 120 & 21 & $27 / 38 / 79 * *$ & \multirow{2}{*}{$\begin{array}{l}\text { ** acetic acid/acetol/formic } \\
\text { acid }\end{array}$} & [67] \\
\hline $3 w t \% R u / C$ & Bio-oil & 52 & 120 & 6 & $33 / 99 / 97 * *$ & & [67] \\
\hline $\mathrm{Ru} / \mathrm{Zr}-\mathrm{MOFs}$ & Furfural & 5 & 20 & 5 & $20-95$ & $\begin{array}{l}\text { TOF: } 2-11 \text { Selectivity to } \\
\text { Furfuryl alcohol: } 20-95\end{array}$ & [68] \\
\hline $\begin{array}{l}\text { AuNCs/CNTs } \\
\text { membrane }\end{array}$ & 4-nitro-phenol & & & & $53 / 100$ & $5 / 10 \mu \mathrm{mol} \mathrm{Au} / 17 \mathrm{~cm}^{2}$ & [69] \\
\hline $\mathrm{Au} / \mathrm{SiO}_{2}$ & 25 compounds & 80 & 6 & $5-24$ & $40-99$ & $\begin{array}{l}1 \mathrm{mmol} \text { of alkyne, } 0.01 \\
\text { mmol of Au, and } 1 \mathrm{mmol} \text { of } \\
\text { piperazine }\end{array}$ & [70] \\
\hline $\mathrm{Re}-\mathrm{Pd} / \mathrm{SiO}_{2}$ & Stearic acid & 80 & 140 & 1 & 15 & \multirow{2}{*}{$\mathrm{Re} / \mathrm{Pd}=1 / 8$} & [71] \\
\hline $\mathrm{Re}-\mathrm{Pd} / \mathrm{SiO}_{2}$ & Stearic acid & 80 & 140 & 4 & 13 & & [71] \\
\hline $\mathrm{Ni} /$ rutile & Crotonaldehyde & 10 & 70 & & 60 & & [72] \\
\hline $\mathrm{Pd}-\mathrm{Cu} / \mathrm{MgO}$ & Furfural & $6-8$ & $80-130$ & 0.5 & 100 & $\begin{array}{l}\text { 98.7\% selectivity of } \\
\text { Furfuryl alcohol }\end{array}$ & [73] \\
\hline $\mathrm{Pt} / \mathrm{MWNT}$ & Furfural & 20 & 150 & 5 & $75-100$ & $\begin{array}{l}\text { Max Furfuryl alcohol } \\
\text { selectivity: } 79 \%\end{array}$ & [74] \\
\hline $\mathrm{ReOx}-\mathrm{Pd} / \mathrm{CeO}_{2}$ & 16 compounds & 80 & 140 & 4 & $1-60$ & $\begin{array}{c}\text { substrate } 0.5 \mathrm{~g}, 1,4 \text { dioxane } \\
4 \mathrm{~g}, \mathrm{Wcat}=150 \mathrm{mg}(2 \mathrm{wt} \% \\
\text { Re, } 0.3 \mathrm{wt} \% \mathrm{Pd})\end{array}$ & [75] \\
\hline $\begin{array}{c}\mathrm{Rh}- \\
\mathrm{MoOx} / \mathrm{SiO}_{2}+ \\
\mathrm{CeO}_{2}\end{array}$ & cyclohexanecarboxamide & 80 & 140 & 4 & 89 & & [76] \\
\hline
\end{tabular}

Liao et al. [77] used $\mathrm{CeO}$ as support with different metals ( $\mathrm{Ni}, \mathrm{Co}$, and $\mathrm{Cu}$ ) for the hydrogenation in liquid phase of maleic anhydride at 50 bar and $210{ }^{\circ} \mathrm{C}$, converting all the reactant after 60,180 , and $420 \mathrm{~min}$, for $\mathrm{Ni}, \mathrm{Co}$, and $\mathrm{Cu}$, respectively. Elliott al. [78] elaborated a reactivity scale of hydrogenation of different organic compounds in presence of CoMo and NiMo sulphided catalysts (see Figure 3) based on literature work [79]. Olefins, aldehydes, and ketones were hydrogenated at low temperatures as low as $150-200{ }^{\circ} \mathrm{C}$, while the alcohols at $250-300{ }^{\circ} \mathrm{C}$. Carboxylic and phenolic ethers reacted at around $300{ }^{\circ} \mathrm{C}$.

Recently, copper catalysts have attracted much attention for the conversion of glycerol to propylene glycol because of their intrinsic ability to selectively cleave the $\mathrm{C}-\mathrm{O}$ bonds in glycerol rather than the $\mathrm{C}-\mathrm{C}$ bonds. To increase the activity of $\mathrm{Cu}$ metal, $\mathrm{Cu}$-based catalysts such as $\mathrm{Cu}-\mathrm{Cr}, \mathrm{Cu}-\mathrm{Al}$, and $\mathrm{Cu}-\mathrm{Mg}$ have been developed to promote the hydrogenolysis reaction. Bienholz et al. prepared a highly dispersed silica-supported copper catalyst $\left(\mathrm{Cu} / \mathrm{SiO}_{2}\right)$ using an ion-exchange method and achieved $100 \%$ glycerol conversion with $87 \%$ propylene glycol selectivity at optimum conditions of $5 \mathrm{~mL} / \mathrm{h}$ of $40 \mathrm{wt} \%$ aqueous glycerol solution, $255^{\circ} \mathrm{C}$, and $300 \mathrm{~mL} / \mathrm{min}$ of $\mathrm{H}_{2}$ at 15 bar [80]. Liu's group studied the glycerol hydrogenolysis over $\mathrm{Ru}-\mathrm{Cu}$ catalysts supported on different support materials including $\mathrm{SiO}_{2}, \mathrm{Al}_{2} \mathrm{O}_{3}, \mathrm{NaY}$ zeolite, $\mathrm{TiO}_{2}, \mathrm{ZrO}_{2}$, and $\mathrm{HY}$ zeolite. The best activity was observed for $\mathrm{Ru}-\mathrm{Cu} / \mathrm{ZrO}_{2}$ with $100 \%$ glycerol conversion and $78.5 \%$ propylene glycol selectivity. The high activity of this catalyst was attributed to the synergistic effect of $\mathrm{Ru}$ in the catalyst related to hydrogen spill-over, while the high selectivity was attributed mainly to the low acidity of the support and the $\mathrm{Cu}$ amount [81].The HDO of the Water soluble fraction of Bio-Oil (WBO) at different temperatures $\left(220,270\right.$, and $310{ }^{\circ} \mathrm{C}$ ) at 190 bar, using $5 \mathrm{wt} \%$ $\mathrm{Ru} / \mathrm{C}$ catalyst, was studied by de Miguel Mercader et al. [82], where the recovery of carbon in oil phase increased from $16.3 \mathrm{wt} \%$ to $38.5 \mathrm{wt} \%$, when the temperature was increased from 220 to $310^{\circ} \mathrm{C}$. In another study, several lignin model compounds (phenol, m-cresol, anisole, guaiacol, and diphenyl ether) were tested for $\mathrm{HDO}$ reactions in presence of $\mathrm{MoO}_{3}$ at atmospheric pressure and temperature between 150 and $250{ }^{\circ} \mathrm{C}$ [83]. The authors noted that, according to the bond dissociation energy, the highest catalytic reactivity was obtained 
with diphenyl ether, but important carburization phenomena have been noted onto the catalyst surface.

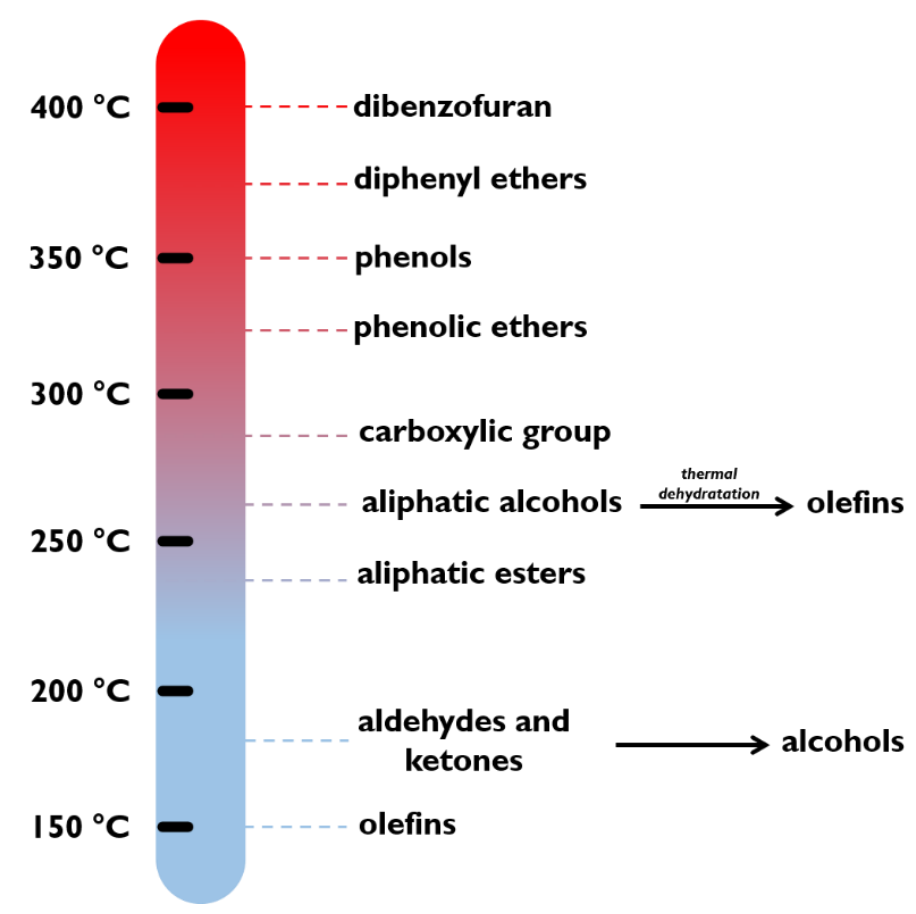

Figure 3. Reactivity scale of organic compounds under hydrotreatment conditions. Adapted with permission from [78].

Bagnato et al. [84] prepared by impregnation technique a series of monometallic and bimetallic metal catalysts in which the zirconia was doped with Pd and not noble metals ( $\mathrm{Cu}$ and $\mathrm{Fe}$ ), characterized, and their performances studied in term of conversion and selectivity for key bio-compounds. Vanillin was completely converted after $80 \mathrm{~min}$ at $100{ }^{\circ} \mathrm{C}$ and 50 bar, in presence of $\mathrm{PdFe} / \mathrm{ZrO}_{2}$. Meanwhile, the PdFe reached the conversion of $65.5 \%$ and $20 \%$ for furfural to furfuryl alcohol and glucose to sorbitol $(74 \%$ selectivity), respectively.

The authors noted that the bimetallic catalyst was able to improve the conversion than the monometallic, mainly due the adsorption mechanism onto the catalytic surface: the not noble metal favoured the bonding to the aldehyde group, while the noble metal favoured the hydrogen molecule adsorption.

Bergem et al. [67] investigated the $\mathrm{HDO}$ of a model $\mathrm{WBO}$ using $\mathrm{Ru} / \mathrm{TiO}_{2}$ and $\mathrm{Ru} / \mathrm{C}$ catalysts in a packet bed reactor (PBR) at a temperature between 100 and $140{ }^{\circ} \mathrm{C}, \sim 62 \mathrm{bar}$. A completed conversion was noted already a $100{ }^{\circ} \mathrm{C}$ for compounds such as acetone, acetaldehyde, propionaldehyde, 2-propen-1-ol, 1-hydroxy-2-butanone, 3-hydroxy-2-butanone, 2hexanone, and 2-furanone. Other compounds such as furfural and hydroxyacetaldehyde required elevate temperature $\left(>140^{\circ} \mathrm{C}\right)$ for converting completely. Furthermore, the authors observed a decrement of catalyst activity, about $25 \%$ after $90 \mathrm{~h}$, due at acid leaching. Sanna et al. [85] studied the HDO of a real WBO in presence of $\mathrm{Ru} / \mathrm{C}$ and $\mathrm{Pt} / \mathrm{C}$ catalysts in a two-stage continuous reactor. In the first stage, the reaction was carried out in presence of $\mathrm{Ru} / \mathrm{C}$ catalyst at $125^{\circ} \mathrm{C}$, while in the second stage, it was carried out at a temperature between 200 and $250{ }^{\circ} \mathrm{C}$ with $\mathrm{Pt} / \mathrm{C}$, at 50 and $100 \mathrm{bar}$, and different weight hourly space velocities from 0.75 to $6 \mathrm{~h}^{-1}$. During the first low temperature stage, the unstable bio-oil functionalities were stabilized into alcohols, where the main products were ethylene glycol, propylene glycol, and sorbitol, losing 7\% of carbon as gas and solid phase. Furthermore, the catalyst showed a constant activity for about $80 \mathrm{~h}$. In the second-high temperature stage, $45 \%$ of the carbon was converted in gasoline blend stocks and $C_{2}$ to $C_{6}$ diols. 


\subsection{Kinetic Mechanism}

The reactions involved during the hydrotreating of bio-oil have been widely studied [86-88], as shown below:

$$
\begin{gathered}
\text { Hydrodeoxygenation (HDO) }: \mathrm{R}-\mathrm{OH}+\mathrm{H}_{2} \rightarrow \mathrm{R}-\mathrm{H}+\mathrm{H}_{2} \mathrm{O} ; \\
\text { Hydrodesulphurisation (HDS) }: \mathrm{R}-\mathrm{SH}+\mathrm{H}_{2} \rightarrow \mathrm{R}-\mathrm{H}+\mathrm{H}_{2} \mathrm{~S} ; \\
\text { Hydrodenitrogenation (HDN) }: \text { Pyridine }+\mathrm{H}_{2} \rightarrow \text { Pentane }+\mathrm{NH}_{3} ; \\
\text { Hydrodealkylation : } \mathrm{R}-\mathrm{C}_{6} \mathrm{H}_{5}+\mathrm{H}_{2} \rightarrow \mathrm{C}_{6} \mathrm{H}_{6}+\mathrm{R}-\mathrm{H} ; \\
\text { Hydrocracking: } \mathrm{R}_{1}-\mathrm{CH}_{2} \mathrm{CH}_{2}-\mathrm{R}_{2}+\mathrm{H}_{2} \rightarrow \mathrm{R}_{1}-\mathrm{CH}_{3}+\mathrm{R}_{2}-\mathrm{CH}_{3} ; \\
\text { Isomerisation of alkanes : } n-\text { alkane } \rightarrow i-\text { alkane; } \\
\text { Decarboxylation : } \mathrm{R}-\mathrm{CO}-\mathrm{OH} \rightarrow R-\mathrm{H}+\mathrm{CO}_{2} ; \\
\text { Decarbonilation : } \mathrm{R}-\mathrm{CHO} \rightarrow \mathrm{R}-\mathrm{H}+\mathrm{CO} ; \\
\text { Water gas shift reaction : } \mathrm{CO}_{2}+\mathrm{H}_{2} \leftrightarrow \mathrm{CO}+\mathrm{H}_{2} \mathrm{O} ; \\
\text { Coke formation : polyaromatic } \rightarrow \text { coke. }
\end{gathered}
$$

In the following section, the reaction mechanisms of some of the most representative bio-oil compounds will be discussed.

\subsubsection{Phenol}

The phenol hydrogenation has been widely studied [89-93]. The reaction pathways are shown in Figure 4, where hydrogen reacts with the phenol (PHE) attacking the hydroxyl group to produce benzene with subsequent production of cyclohexene (CHE) and cyclohexane (CHO). Another reaction pathway of the aromatic ring is the formation of cyclohexanol $(\mathrm{CXO})$ with consecutive hydrogenation in cyclohexene and cyclohexane. A further reaction pathway is represented by the formation of cyclohexanone (COL) with subsequent cyclohexanol hydrogenation in cyclohexene and cyclohexane. Finally, methylcyclopentane $(\mathrm{MCP})$ can be produced by isomerization reaction.

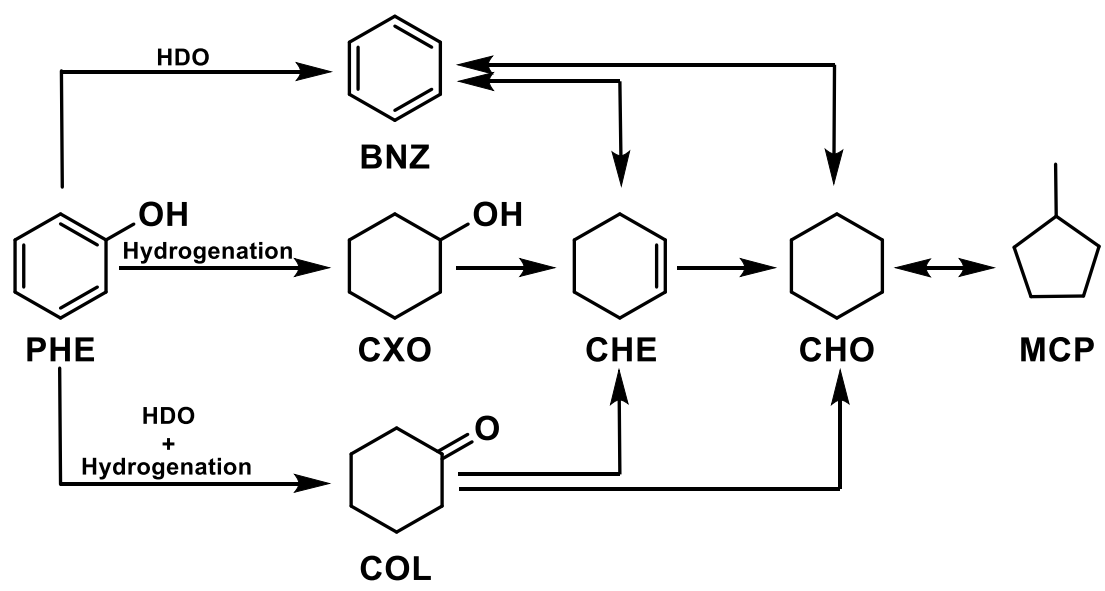

Figure 4. Phenol hydrogenation pathways. 


\subsubsection{Guaiacol}

Another representative compound in bio-oil is guaiacol that reacts forming phenol [39-43] via two paths: (1) direct demethoxylation; and (2) indirect reaction through demethylation to catechol with subsequent hydrogenation of the latter compound. The undesired polymerisation of guaiacol (GCL) (Figure 5) leads to coke formation.

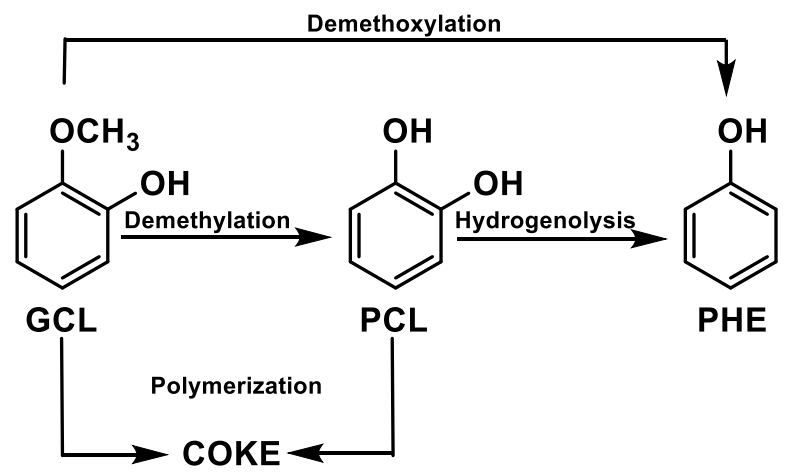

Figure 5. Guaiacol reaction path.

Bindwal et al. [94] proposed a kinetic rate for the hydrogenation of guaiacol in 1,2 cycloexanediol in presence of $5 \% \mathrm{Ru} / \mathrm{C}$ catalyst according to the Langmuir-Hinshe-woodHougen-Watson (LHHW) model. The authors, according to the experimental data obtained, identified the limitation step for the reaction taking place on the catalyst surface, assuming the dissociative adsorption of $\mathrm{H}_{2}$. The reaction rate was described by the following equation:

$$
r=\frac{k_{3, a} K_{B} C_{B} \sqrt{K_{H_{2}} C_{H_{2}}}}{\left(1+\sqrt{K_{H_{2}} C_{H_{2}}}+K_{B} C_{B}\right)^{2}},
$$

where $C_{B} C_{H 2}$ are the molar concentration of guaiacol and hydrogen, respectively, $k_{3, a}$ the kinetic constant, $K_{B}$ and $K_{H 2}$ are the adsorption constant of guaiacol and hydrogen.

\subsubsection{Levoglucosan}

The hydrolysis of levoglucosan has been studied in a solution of water and in the presence of $\mathrm{Ru} / \mathrm{C}$ [95]. The path involves the production of glucose (hydrolysis reaction) with subsequent hydrogenation into sorbitol. Finally, ethylene glycol, 1,2-Propanediol, and 1,4-Butanediol are produced by the hydrogenation of sorbitol (Figure 6).

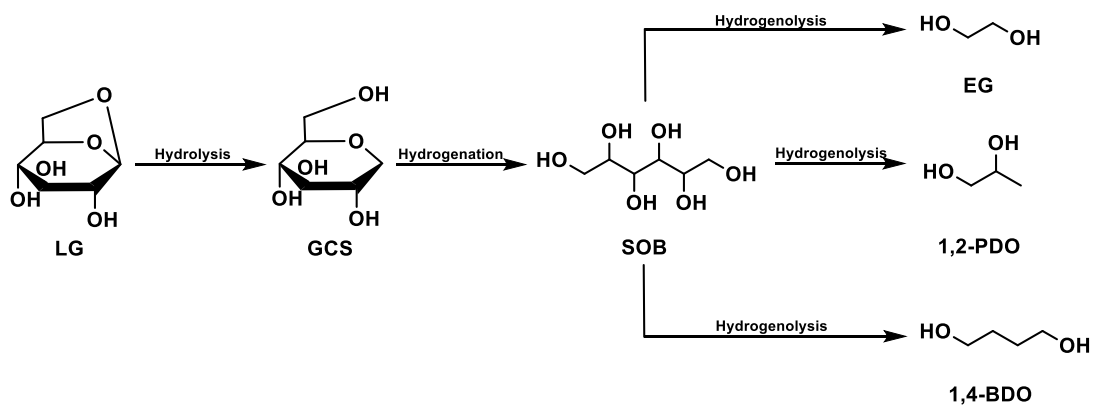

Figure 6. Levoglucosan reaction path. 
Bindwal et al. [95] proposed a kinetic rate for the hydrogenation in presence of $\mathrm{Ru} / \mathrm{C}$, where the $\mathrm{H}_{2}$ and levoglucosan (LG) chemisorbed and dissociated on the surface catalyst are as follows:

$$
\begin{gathered}
H_{2}+X \leftrightarrow 2 H X, \\
L G+X \leftrightarrow L G X, \\
2 H X+L G X \leftrightarrow \text { products, }
\end{gathered}
$$

represented by the following equation:

$$
r=\frac{k_{3} K_{H 2} K_{L G} C_{H 2} C_{L G}}{\left(1+\sqrt{K_{H 2} C_{H 2}}+K_{L G} C_{L G}\right)^{3}} .
$$

\subsubsection{Other Compounds}

Bindwal et al. [94] studied the kinetics rate of other compounds using 5\% Ru/C catalyst to convert hydroxycetone, hydroxyacetaldehyde and 2-furanone in 1,2 propanediol, ethylene glycol and $\gamma$-butyrolactone, according to the reactions in Figure 7.

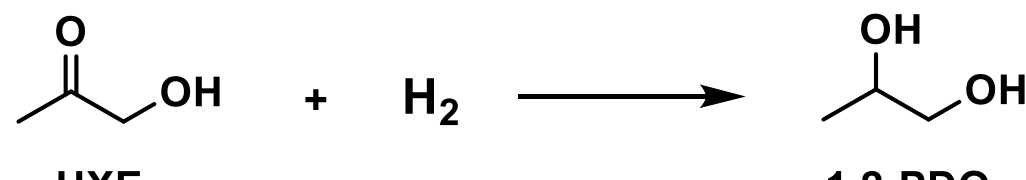

HXE

HO

HXD<smiles>O=C1C=CCO1</smiles>

2-FN

\section{1,2-PDO}<smiles>OCCO</smiles>

EG<smiles>O=C1CCCO1</smiles>

$\gamma$-BCT

Figure 7. Hydrogenation of hydroxyacetone, hydroxyacetaldehyde, and 2-furanone.

The authors proposed different kinetics rates varying the limitation step and the possibility to have an atomic or molecular $\mathrm{H}_{2}$ adsorption.

The kinetics rates hypothesized were validated experimentally confirming that the reactions are surface-reaction limited in presence of dissociative adsorption of $\mathrm{H}_{2}$. The equation for the kinetics rate were

$$
\begin{aligned}
& r=\frac{k_{3} \sqrt{K_{\mathrm{H}_{2}} C_{\mathrm{H}_{2}}} K_{B} C_{B}}{\left(1+\sqrt{K_{\mathrm{H}_{2} C_{H_{2}}}}+K_{B} C_{B}\right)^{2}}, \\
& r=\frac{k_{3} K_{\mathrm{H}_{2}} K_{B} C_{H_{2}} C_{B}}{\left(1+\sqrt{K_{\mathrm{H}_{2}} C_{\mathrm{H}_{2}}}+K_{B} C_{B}\right)^{3}} .
\end{aligned}
$$

Zhang et al. $[96,97]$ described the reaction kinetics by dividing the products as Light oil ranged from $36{ }^{\circ} \mathrm{C}$ to $250{ }^{\circ} \mathrm{C}$, heavy oil from $250{ }^{\circ} \mathrm{C}$ to $450{ }^{\circ} \mathrm{C}$, vapors, water, and 
coke. They assumed a series of parallel reactions with a first-order kinetics in presence of $\mathrm{CoMo} / \gamma \mathrm{Al}_{2} \mathrm{O}_{3}$ catalyst.

$$
\begin{gathered}
\text { Bio-oil } \underset{k_{1}}{\rightarrow} \text { light fraction oil, } \\
\text { Bio-oil } \underset{k_{2}}{\rightarrow} \text { heavy fraction oil } \underset{k_{4}}{\rightarrow} \text { light fraction oil, } \\
\text { Bio-oil } \underset{k_{2}}{\rightarrow} \text { heavy fraction oil } \underset{k_{5}}{\rightarrow} \text { gas }+ \text { water }+ \text { char, } \\
\text { Bio - oil } \underset{k_{3}}{\rightarrow} \text { gas }+ \text { water + char. }
\end{gathered}
$$

Furthermore, Sheu et al. [98] divided the bio-oil into six groups (heavy non-volatiles, light non-volatile, phenols, aromatics, alkanes, Coke $+\mathrm{H}_{2} \mathrm{O}+$ Outlet Gases) and used three different catalysts $\left(\mathrm{Pt} / \mathrm{Al}_{2} \mathrm{O}_{3} / \mathrm{SiO}_{2}, \mathrm{CoMo} / \gamma-\mathrm{Al}_{2} \mathrm{O}_{3}\right.$, and $\left.\mathrm{Ni}-\mathrm{W} / \gamma-\mathrm{Al}_{2} \mathrm{O}_{3}\right)$ to study the hydrogenation of bio-oil. Moreover, the authors proposed a reaction pathway by series-parallels of first-order reactions.

$$
\begin{gathered}
\text { heavy nonvolatiles } \underset{k_{1}}{\rightarrow} \text { light nonvolatiles } \underset{k_{3}}{\rightarrow} \text { phenols, } \\
\text { heavy nonvolatiles } \underset{k_{2}}{\rightarrow} \text { aromatics }+ \text { alkanes, } \\
\text { phenols } \underset{k_{4}}{\rightarrow} \text { aromatics }+ \text { alkanes } \underset{k_{5}}{\rightarrow} \text { Coke }+\mathrm{H}_{2} \mathrm{O}+\text { outlet gases. }
\end{gathered}
$$

$k_{i}$ is a kinetic constant and depend of the temperature and pressure by

$$
k_{i}=k_{i 0} P^{n_{i}} \exp \left(-\frac{E a}{R T}\right),
$$

where $k_{i 0}$ and $n_{i}$ are the parameters of the reaction and the catalysts used.

\subsection{Reactor Technologies}

\subsubsection{Conventional Reactors}

The hydrogenation reaction is largely used in refinery to convert the heavy oil fraction into light hydrocarbons. The existing process have been based on the following reactors: fixed beds (FBRs), moving beds (MBRs), and expanded or ebullated beds (EBRs). The main difference among the reactors involves the transport phenomena and some technical details.

The FBRs are the main reactor systems used commercially and used for hydrogenating light hydrocarbon mixture such as naphtha and middle distillate. The FBRs are designed for operating in an adiabatic condition. The reactor is divided into three catalytic zones separated to an inert material (ceramic balls), the liquid and gas stream through the first catalytic bed. The output fed exchange heat by the inert bed and subsequently quenched adding fresh gas reactant and then fed inlet of the second catalytic bed. The output of the second reactor is cooled again by the inert bed and by quenching. EBR reactors have been also used to hydrogenate feeds such as vacuum residue.

The EBRs are used for heavy feeds with a large amount of metals and asphaltenes, where the liquid and gas streams are fed from bottom expanding and mixing the catalyst bed, reducing the pressure drop effect. In the output of the catalytic bed the hydrogen not reacted is recycled, while the liquid products are recovered by a flash unit.

\subsubsection{Membrane Reactor}

The main disadvantage of hydrogenation reaction is represented by mass transport limitation, because the reaction takes place in contact with the gaseous, liquid, and solid phase. The system has to have a high operating pressure, improving the gas solubility into the liquid system and high temperature to advantage the kinetic, but at the same time, the $\mathrm{H}_{2}$ solubility decreases under those conditions. A membrane reactor (MR) is an operation unit to produce new species by chemical reaction and separation process in a 
single equipment [99]. The use of MRs can reduce the process footprint, since the plant will be more compact and can result in lower investment costs, improving the economics of the process [100,101].

In a MBR, the fresh catalyst is fed from the top and trough the reactor, while the reactant stream is fed from the bottom. Afterthought, the products leave the MBR and the deactivated catalyst is sent to the regenerator reactor, where the coke deposition is burned and the activated catalyst returns to MBR.

One of the features of the MRs is to act as a contactor between the three phases during $\mathrm{HDO}$ reaction. Furthermore, the membrane can have catalytic activity chancing the product distribution as reported by Liu et al. [102], who compared packed bed MR and catalytic MR for the hydrogenation of nitrobenzene in presence of $\mathrm{Pd} / \gamma-\mathrm{Al}_{2} \mathrm{O}_{3}$ catalyst. The CMMR showed best performance in term of conversion and catalytic stability ( $\sim 5 \%$ for $10 \mathrm{~h}$ ) as shown in Figure 8.

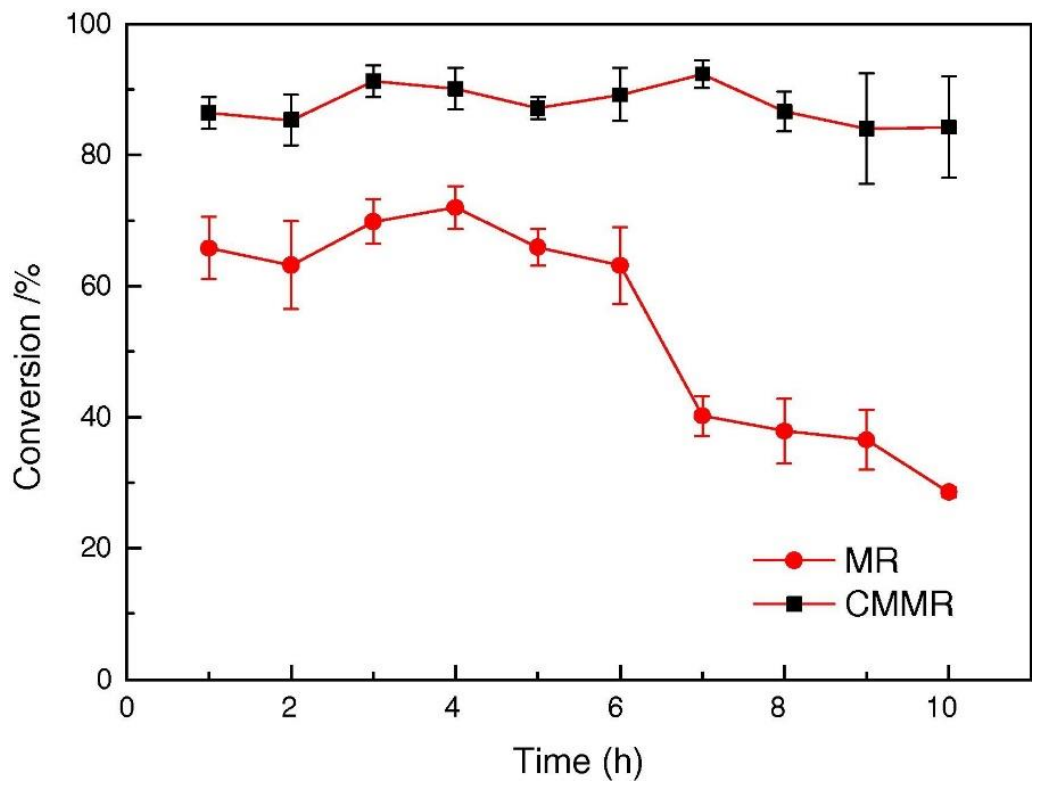

Figure 8. Comparison between catalytic membrane reactor (CMR) and packed bed membrane reactor (PBMR) [102].

Liu et al. [103] studied the selectivity hydrogenation of butadiene in butene at $40{ }^{\circ} \mathrm{C}$ and 10 bar by catalytic membrane reactors (CMRs), obtaining a butene selectivity higher than $99 \%$ and butadiene concentration in the output stream lower than $10 \mathrm{ppm}$. Another example of hydrogenation reaction is reported in Table 4. Despite the increasing interest in catalytic membranes, the HDO of bio-oil in MR is a novelty, since in literature there is only one article [104] available on the topic, where the authors used a MR for the hydrogenation of levulinic acid (compound present in bio-oils) by a porous expanded polytetrafluoroethylene (ePTFE) membrane with Ru catalyst particles. Moreover, the same membranes were coated only in one side with a dense Matrimid layer, which was used to control the hydrogen flux through the membrane. The reaction was studied in a temperature and reaction pressure between 40 and $90^{\circ} \mathrm{C}$ and 0.7 and 5.6 bar, respectively. Furthermore, the authors compared the result obtained with a PBR as shown in Figure 9, where the kinetic rate is presented as ratio of gamma-valerolactone product $(\mathrm{g} / \mathrm{h})$ over grams of $\mathrm{Ru}$. In particular, the MR without the Matrimid layer obtained the best performance (four times more than PBR) with a conversion of $0.0065 \%$, while the MR with the control layer (Matrimid) showed a kinetic rate two times less than the PBR.

Recent studies have emphasized the functionality of MR to be able to achieve a TOF equal to $48,000 \mathrm{~h}^{-1}$ for the partial hydrogenation of furfural in presence of Rupolyethersulfone (PES) catalytic membrane at $70^{\circ} \mathrm{C}$ and 7 bar [105]. 


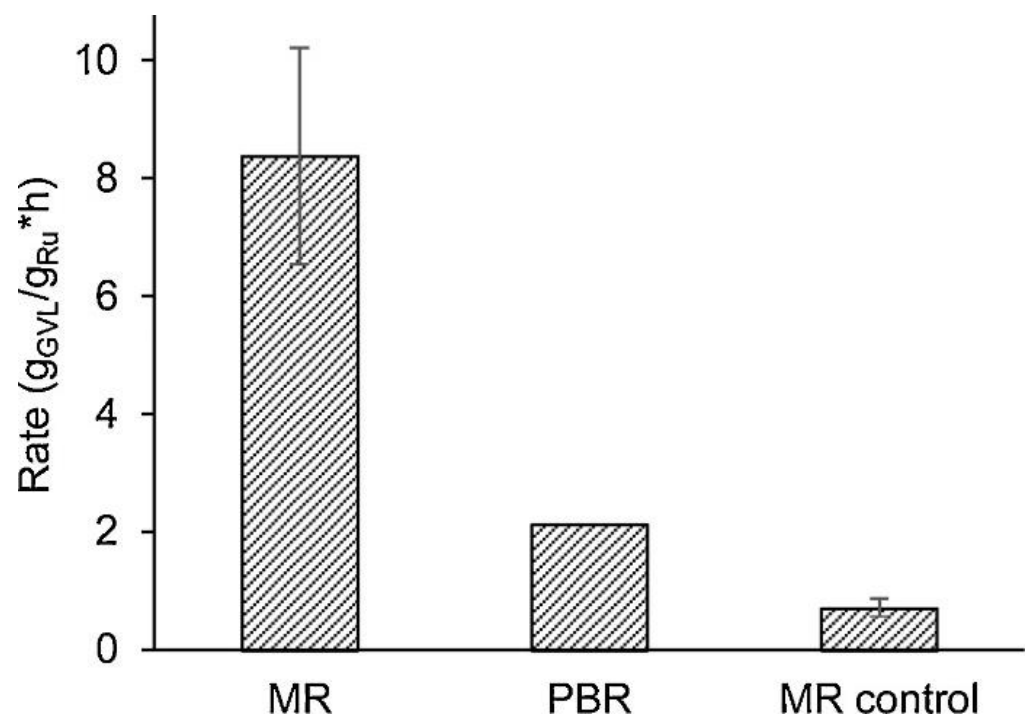

Figure 9. Kinetic rate of hydrogenation of levulonic acid using membrane reactors (MRs) and a packet bed reactor (PBR) [104].

Table 4. MR for hydrogenation reaction.

\begin{tabular}{|c|c|c|c|c|c|c|}
\hline Hydrogenation of & Catalyst & Support & & Pressure (bar) & $\begin{array}{c}\text { Temperature } \\
\left({ }^{\circ} \mathrm{C}\right)\end{array}$ & Ref. \\
\hline 3-hexyn-1-ol & $\begin{array}{l}\text { Pd nanoparticles } \\
(4.6 \mathrm{~nm})\end{array}$ & $\begin{array}{l}\text { zirconia/polyvinyl } \\
\text { alcohol }\end{array}$ & Batch & $5-10$ & 25 & [106] \\
\hline Nitrite & $\mathrm{Pd}$ & $\gamma-\mathrm{Al}_{2} \mathrm{O}_{3}$ & Continuous & 1 & 25 & [107] \\
\hline $\begin{array}{l}\text { Methylenecyclohexane } \\
\text { (and isomerization) }\end{array}$ & $\mathrm{Pt}, \mathrm{Pd}, \mathrm{Ru}$ in $\gamma-\mathrm{Al}_{2} \mathrm{O}_{3}$ & macroporous $\alpha-\mathrm{Al}_{2} \mathrm{O}_{3}$ & Continuous & 1.5 liquid 2 gas & $15-70$ & [108] \\
\hline Methylenecyclohexane & Pd-PVDS PVP & macroporous $\alpha-\mathrm{Al}_{2} \mathrm{O}_{3}$ & Continuous & & $25-50$ & {$[109] *$} \\
\hline Edible oil & $\mathrm{Pd}, \mathrm{Pt}$ & $\begin{array}{l}\text { porous polyamideimide } \\
\text { (PAI) }\end{array}$ & Continuous & 4 & 100 & [110] \\
\hline Nitrobenzene & $\mathrm{Pd}$ & $\begin{array}{c}\text { zirconia/polyvinyl } \\
\text { alcohol }\end{array}$ & Continuous & $1-2$ & 25 & [111] \\
\hline Nitrobenzene & $\begin{array}{c}\mathrm{Pd} / \gamma-\mathrm{Al}_{2} \mathrm{O}_{3} \\
\text { PVP-Pd, PVP-Pd, }\end{array}$ & PDMS & Continuous & $1-2$ & 20 & [102] \\
\hline Butadiene & $\begin{array}{c}\text { EC-Pd, AR-Pd, AR-Pd, } \\
\text { PVP-Pd, PVP-Pd-0.5 } \\
\mathrm{Co}(\mathrm{OAc})_{2}, \mathrm{PVP}-\mathrm{Pd}-0.5 \\
\mathrm{Co}(\mathrm{OAc})_{2}\end{array}$ & $\begin{array}{c}\text { CA, PSF, CA, CA, PSF, } \\
\text { CA, CA, CA }\end{array}$ & Continuous & 10 & 40 & {$[103]^{* *}$} \\
\hline Furfural & $\mathrm{Ru}$ & PES & Continous & 7 & 70 & [105] \\
\hline
\end{tabular}

* Ceramic membrane showed a higher selectivity toward the hydrogenated product than the polymeric membrane but exhibited a lower TON (= converted moles in a second per gram of $\mathrm{Pd}$ ) value. ${ }^{* *} \mathrm{PVP}-\mathrm{Pd}-0.5 \mathrm{Co}(\mathrm{OAc})_{2}$ showed best performance. The presence of $\mathrm{Co}$ inhibited isomerization reaction.

\section{Concluding Remarks and Future Outlook}

The valorization of biomass and residues for the production of liquid fuels by both thermochemical (e.g., pyrolysis) or physical (e.g., pressing) methods has attracted a great attention from both scientific and technological point of view. In fact, the utilization of vegetable raw materials for the production of synthetic chemical intermediates and hydrocarbons is considered one of the most investigated strategies aimed at reducing both the carbon dioxide emissions and the dependence on fossils fuels.

In this review, we summarize the main aspects related to pyrolysis and to the properties of the obtained bio-oils, focusing great attention to the hydrotreatment process alternatives for converting the pyrolysis bio-oil into drop-in fuel.

Research studies usually are focused on the pyrolysis of a well-defined biomass, while a limited number of papers are devoted to biomass residues with variable composition. The former approach is useful for understanding the complex mechanism involved during the pyrolysis and the effect of process parameters on reaction pathways, while the latter is 
of paramount importance for developing the technology at a pilot and demonstrative scale. In fact, the compositional variations in the feedstock modify both yield and composition of bio-oil, and this aspect has a significant impact on the viability of the process. As previously mentioned, biomass availability at a low cost is one of the biggest challenges of biorefinery. Therefore, more effort should be put on the experimental investigation at a pilot and demonstrative scale on the production of bio-oil from biomass residues with a large compositional variability. The research is also focused on the role of biomass pre-treatment on bio-oil quality. In particular, physical, chemical, and thermal methods may be adopted. As an example, the modification of size and shape of biomass particles has an effect on heat transfer with an impact on bio-oil quality. Whereas, the reduction of hemicellulose by a thermal method, such as torrefaction, decreases the amount of organic acids, acetals, and water in the bio-oil, with a positive impact on bio-oil stability, but with a higher inorganics content. The amount of inorganics may be reduced by physical pre-treatment such as biomass washing with water or acids. Unfortunately, there is a lack of information and knowledge about the economic feasibility of the biomass pre-treatment methods. Another important aspect that should be investigated in more detail is the stability of produced bio-oil. In fact, the bio-oil is a complex mixture containing water and both polar and nonpolar organics that cause several reactions, e.g., oligomerization condensation and dehydration, with aging of the bio-oil and formation of a more complex multiphase systems. The addition of alcohols, such as methanol, usually improves stability, homogeneity, and viscosity of bio-oil. Further research on bio-oil stabilization is needed to address technical issues during bio-oil storage and processing.

This review aims to summarize recent advances on the conversion to pyrolysis bio-oil into drop-in fuels by catalytic hydrogenation. In this regard, the research efforts should be better focused on (i) catalytic assessment of novel catalysts, and (ii) experimental investigation at pilot and demonstrative scale of hydrotreatment of real bio-oil. Concerning the first point, several metals and metals supported over moderately acid solids have been investigated. Ni-Mo or Co-Mo bimetallic systems supported over gamma-alumina are the most investigated catalysts for hydrotreatment, since they are well-known catalysts for hydroprocessing oil-derived streams, i.e., hydrodesulphurization. In these systems, Mo represents the active phase for the removal of heteroatoms, while $\mathrm{Ni}$ or Co acts as promoters for the hydrogenation step. Several alternative catalysts have been studied mostly for the hydrogenation of model compounds, whose catalytic behavior is in part discussed in this review. For instance, different metals and different supports have been studied, while a less attention was paid to the design of innovative hybrid systems, where the catalytic functionalities requested by the process, e.g., redox, acids, are carefully tuned with the aim to improve catalyst effectiveness. In this regard, research should be also devoted to the study of reaction mechanism as a function of surface properties of the catalysts. This approach has brought advances in other fields, such as hydrogenation of carbon dioxide to synthetic fuels, and it may be useful for a better understanding of catalysis of hydrogenation of bio-oils.

Nevertheless, bio-oil strongly differs from typical crude oil derived streams, due to the presence of a large amount of oxygenated compounds, e.g., carboxylic acids, phenols, aldehydes, ketones, sugars, and water. For this reason, the physic-chemical features of the catalyst for hydrotreatment of bio-oil should be carefully tuned as a function of biooil composition. On the contrary, a limited number of studies were carried out on the hydrotreatment of real pyrolysis bio-oil. In that case, the number of variables and the issues strongly increase. As an example, the presence of unsaturated oligomers in real bio-oil may lead to the formation of coke with deactivation of the catalyst. Therefore, future focus should be on the separation of bio-oil fractions in order to assess the most suitable bio-oil cut for hydroprocessing. In fact, the presence of oligomers inevitably causes a large amount of coke formation with catalyst deactivation. Of course, the presence of an additional step between pyrolysis and hydrotreatment has a significant effect on the process costs. The experimental investigation of hydrotreatment of bio-oil fractions at an either pilot or 
demonstrative scale may push towards more research in the field of bio-oil pre-treatments, as well as address also challenges, such as hydrogen consumption. In fact, most of the papers on hydrotreatment of bio-oil or bio-oil models are focused on product yield and quality, but it is difficult to find quantitative information on hydrogen consumption, which is usually used in large excess. As in the case of pyrolysis step, investigations at scales larger than laboratory of hydrogenation steps may surely provide quantitative data useful for viability studies on the production of drop-in fuels from biomass via pyrolysis.

Author Contributions: Conceptualization and organization: G.B., E.P. and E.C.; Writing-original draft preparation: G.B., A.S., E.P. and E.C.; Writing—review and editing: E.P.; All authors have read and agreed to the published version of the manuscript.

Funding: This research received no external funding.

Conflicts of Interest: The authors declare no conflict of interest.

\section{Abbreviations}

\begin{tabular}{|c|c|}
\hline BNZ & Benzene \\
\hline $\mathrm{CHE}$ & Cyclohexene \\
\hline $\mathrm{CHO}$ & Cyclohexanol \\
\hline CMR & Catalytic membrane reactor \\
\hline COL & Cyclohexanone \\
\hline $\mathrm{CXO}$ & Cyclohexanol \\
\hline Ea & Activation energy \\
\hline EBR & Ebullated bed reactor \\
\hline EG & Ethylene glycol \\
\hline$\gamma$-BCT & $\gamma$-Butyrolactone \\
\hline GCL & Guaiacol \\
\hline GCS & Glucose \\
\hline $\mathrm{HDO}$ & Hydrodeoxygenation reaction \\
\hline HD & Hydrotreating \\
\hline HTL & Hydrothermal liquefaction \\
\hline HXD & Hydroxyacetaldehyde \\
\hline HXE & Hydroxyacetone \\
\hline k & Kinetic rate \\
\hline $\mathrm{k} 0$ & Pre-exponential number \\
\hline LG & Levoglucosan \\
\hline LHHW & Langmuir-Hinshelwood-Hougen-Watson \\
\hline LHSV & Liquid hourly space velocity \\
\hline MR & Membrane reactor \\
\hline MBR & Moving bed reactor \\
\hline MCP & Methylcyclopentane \\
\hline $\mathrm{n}$ & Kinetic order \\
\hline PBR & Packet bed reactor \\
\hline PBMR & Packed bed membrane reactor \\
\hline PCL & Pyrocatechol \\
\hline PHE & Phenol \\
\hline SOB & Sorbitol \\
\hline TEA & Techno-economical assessment \\
\hline TOF & Turnover of frequency \\
\hline WBO & Water soluble bio-oil fraction \\
\hline 1,2-PDO & 1,2-Propanediol \\
\hline 1,4-BDO & 1,4-Butanediol \\
\hline 2-FN & 2-Furanone \\
\hline
\end{tabular}




\section{References}

1. Anastas, P.; Eghbali, N. Green Chemistry: Principles and Practice. Chem. Soc. Rev. 2010, 39, 301-312. [CrossRef] [PubMed]

2. Ragauskas, A.J.; Williams, C.K.; Davison, B.H.; Britovsek, G.; Cairney, J.; Eckert, C.A.; Frederick, W.J.; Hallett, J.P.; Leak, D.J.; Liotta, C.L.; et al. The Path Forward for Biofuels and Biomaterials. Science 2006, 311, 484-489. [CrossRef] [PubMed]

3. Paone, E.; Tabanelli, T.; Mauriello, F. The rise of lignin biorefinery. Curr. Opin. Green Sustain. Chem. 2020, 24, 1-6. [CrossRef]

4. Paone, E.; Beneduci, A.; Corrente, G.A.; Malara, A.; Mauriello, F. Hydrogenolysis of aromatic ethers under lignin-first conditions. Mol. Catal. 2020, 497, 111228. [CrossRef]

5. Malara, A.; Paone, E.; Frontera, P.; Bonaccorsi, L.; Panzera, G.; Mauriello, F. Sustainable exploitation of coffee silverskin in water remediation. Sustainability 2020, 10, 3547. [CrossRef]

6. Xu, C.; Paone, E.; Rodríguez-Padrón, D.; Luque, R.; Mauriello, F. Recent catalytic routes for the preparation and the upgrading of biomass derived furfural and 5-hydroxymethylfurfural. ChemSocRev 2020, 49, 4273-4306. [CrossRef]

7. Transforming Our World: The 2030 Agenda for Sustainable Development. Available online: https://sustainabledevelopment.un. org/post2015/transformingourworld (accessed on 11 January 2021).

8. Carlos, R.M.; Khang, D.B. Characterization of biomass energy projects in Southeast Asia. Biomass Bioenergy 2008, 32, 525-532. [CrossRef]

9. Paone, E.; Espro, C.; Pietropaolo, R.; Mauriello, F. Selective arene production from transfer hydrogenolysis of benzyl phenyl ether promoted by a co-precipitated $\mathrm{Pd} / \mathrm{Fe}_{3} \mathrm{O}_{4}$ catalyst. Catal. Sci. Technol. 2016, 6, 7937-7941. [CrossRef]

10. Mauriello, F.; Paone, E.; Pietropaolo, R.; Balu, A.M.; Luque, R. Catalytic transfer hydrogenolysis of lignin-derived aromatic ethers promoted by bimetallic Pd/Ni systems. ACS Sustain. Chem. Eng. 2018, 6, 9269-9276. [CrossRef]

11. Espro, C.; Gumina, B.; Paone, E.; Mauriello, F. Upgrading lignocellulosic biomasses: Hydrogenolysis of platform derived molecules promoted by heterogeneous Pd-Fe catalysts. Catalysts 2017, 7, 78. [CrossRef]

12. Espro, C.; Gumina, B.; Szumelda, T.; Paone, E.; Mauriello, F. Catalytic transfer hydrogenolysis as an effective tool for the reductive upgrading of cellulose, hemicellulose, lignin, and their derived molecules. Catalysts 2018, 8, 313. [CrossRef]

13. Mauriello, F.; Ariga-Miwa, H.; Paone, E.; Pietropaolo, R.; Takakusagi, S.; Asakura, K. Transfer hydrogenolysis of aromatic ethers promoted by the bimetallic Pd/Co catalyst. Catal. Today 2020, 357, 511-517. [CrossRef]

14. Malara, A.; Paone, E.; Bonaccorsi, L.; Mauriello, F.; Macario, A.; Frontera, P. Pd $/ \mathrm{Fe}_{3} \mathrm{O}_{4}$ Nanofibers for the Catalytic Conversion of Lignin-Derived Benzyl Phenyl Ether under Transfer Hydrogenolysis Conditions. Catalysts 2020, 10, 20. [CrossRef]

15. Srifa, A.; Chaiwat, W.; Pitakjakpipop, P.; Anutrasakda, W.; Faungnawakij, K. Chapter 6-Advances in bio-oil production and upgrading technologies. In Sustainable Bioenergy; Elsevier: Amsterdam, The Netherlands, 2019; pp. 167-198.

16. Han, Y.; Gholizadeh, M.; Tran, C.-C.; Kaliaguine, S.; Li, C.-Z.; Olarte, M.; Garcia-Perez, M. Hydrotreatment of pyrolysis bio-oil: A review. Fuel Process. Technol. 2019, 195, 106140. [CrossRef]

17. Tabanelli, T.; Paone, E.; Blair Vásquez, P.; Pietropaolo, R.; Cavani, F.; Mauriello, F. Transfer Hydrogenation of Methyl and Ethyl Levulinate Promoted by a $\mathrm{ZrO}_{2}$ Catalyst: Comparison of Batch vs Continuous Gas-Flow Conditions. ACS Sustain. Chem. Eng. 2019, 7, 9937-9947. [CrossRef]

18. Fasolini, A.; Cucciniello, R.; Paone, E.; Mauriello, F.; Tabanelli, T. Short Overview on the Hydrogen Production Via Aqueous Phase Reforming (APR) of Cellulose, C6-C5 Sugars and Polyols. Catalysts 2019, 9, 917. [CrossRef]

19. Xu, C.; Paone, E.; Rodríguez-Padrón, D.; Luque, R.; Mauriello, F. Reductive catalytic routes towards sustainable production of hydrogen, fuels and chemicals from biomass derived polyols. Renew. Sustain. Energy Rev. 2020, 127, 109852. [CrossRef]

20. Weldekidan, H.; Strezov, V.; Town, G. Review of solar energy for biofuel extraction. Renew. Sustain. Energy Rev. 2018, 88, 184-192. [CrossRef]

21. Pistone, A.; Espro, C. Current trends on turning biomass wastes into carbon materials for electrochemical sensing and rechargeable battery applications. Curr. Opin. Green Sustain. Chem. 2020, 26, 100374. [CrossRef]

22. $\mathrm{Hu}, \mathrm{X}$; Gholizadeh, M. Progress of the applications of bio-oil. Renew. Sustain. Energy Rev. 2020, 134, 110124. [CrossRef]

23. Bagnato, G.; Boulet, F.; Sanna, A. Effect of Li-LSX zeolite, $\mathrm{NiCe} / \mathrm{Al}_{2} \mathrm{O}_{3}$ and $\mathrm{NiCe} / \mathrm{ZrO}_{2}$ on the production of drop-in bio-fuels by pyrolysis and hydrotreating of Nannochloropsis and isochrysis microalgae. Energy 2019, 179, 199-213. [CrossRef]

24. Kumar, R.; Strezova, V.; Weldekidan, H.; He, J.; Singh, S.; Kan, T.; Dastjerdi, B. Lignocellulose biomass pyrolysis for bio-oil production: A review of biomass pre-treatment methods for production of drop-in fuels. Renew. Sustain. Energy Rev. 2020, 123, 109763. [CrossRef]

25. Fang, J.; Zhan, L.; Ok, Y.S.; Gao, B. Minireview of potential applications of hydrochar derived from hydrothermal carbonization of biomass. J. Ind. Eng. Chem. 2018, 57, 15-21. [CrossRef]

26. Ullah Khan, I.; Othman, M.H.D.; Hashim, H.; Matsuura, T.; Ismail, A.F.; Rezaei-DashtArzhandi, M.; Wan Azelee, I. Biogas as a renewable energy fuel-A review of biogas upgrading, utilisation and storage. Energy Convers. Manag. 2017, 150, 277-294. [CrossRef]

27. Baker, E.G.; Elliott, D.C. Catalytic Hydrotreating of Biomass-Derived Oils, in Pyrolysis Oils from Biomass. ACS Symp. Ser. 1988, 21, 228-240.

28. Bagnato, G.S.; Sanna, A. Process and Techno-Economic Analysis for Fuel and Chemical Production by Hydrodeoxygenation of Bio-Oil. Catalysts 2019, 9, 1021. [CrossRef]

29. Lima, S.; Fernandes, A.; Antunes, M.M.; Pillinger, M.; Ribeiro, F.; Valente, A.A. Dehydration of Xylose into Furfural in the Presence of Crystalline Microporous Silicoaluminophosphates. Catal. Lett. 2010, 135, 41-47. [CrossRef] 
30. Demirbas, A. Thermochemical Processes. In Biorefineries: For Biomass Upgrading Facilities. Green Energy and Technology; Springer: London, UK, 2010; pp. 135-192.

31. BTG Bioliquids BV. 2020. Available online: https://www.btg-bioliquids.com (accessed on 11 January 2021).

32. Li, F.; Srivatsa, S.C.; Bhattacharya, S. A review on catalytic pyrolysis of microalgae to high-quality bio-oil with low oxygeneous and nitrogenous compounds. Renew. Sustain. Energy Rev. 2019, 108, 481-497. [CrossRef]

33. Furimsky, E. Catalytic hydrodeoxygenation. Appl. Catal. A Gen. 2000, 199, 147-190. [CrossRef]

34. Fisk, C.A.; Morgan, T.; Ji, Y.; Crocker, M.; Crofcheck, C.; Lewis, S.A. Bio-oil upgrading over platinum catalysts using in situ generated hydrogen. Appl. Catal. A Gen. 2009, 358, 150-156. [CrossRef]

35. Li, P.; Chen, X.; Wang, X.; Shao, J.; Lin, G.; Yang, H.; Yang, Q.; Chen, H. Catalytic Upgrading of Fast Pyrolysis Products with Fe-, Zr-, and Co-Modified Zeolites Based on Pyrolyzer-GC/MS Analysis. Energy Fuels 2017, 31, 3979-3986. [CrossRef]

36. Dong, T.; Wang, J.; Miao, C.; Zheng, Y.; Chen, S. Two-step in situ biodiesel production from microalgae with high free fatty acid content. Bioresour. Technol. 2013, 136, 8-15. [CrossRef] [PubMed]

37. Zainan, N.H.; Srivatsa, S.C.; Bhattacharya, S. Catalytic pyrolysis of microalgae Tetraselmis suecica and characterization study using in situ Synchrotron-based Infrared Microscopy. Fuel 2015, 161, 345-354. [CrossRef]

38. Demirbas, A. The influence of temperature on the yields of compounds existing in bio-oils obtained from biomass samples via pyrolysis. Fuel Process. Technol. 2007, 88, 591-597. [CrossRef]

39. Venderbosch, R.H.; Ardiyanti, A.R.; Wildschut, J.; Oasmaa, A.; Heeres, H.J. Stabilization of biomass-derived pyrolysis oils. J. Chem. Technol. Biotechnol. 2010, 85, 674-686. [CrossRef]

40. Oasmaa, A.; Solantausta, Y.; Arpiainen, V.; Kuoppala, E.; Sipilä, K. Fast pyrolysis bio-oils from wood and agricultural residues. Energy Fuels 2010, 2, 1380-1388. [CrossRef]

41. Wildschut, J.; Mahfud, F.H.; Venderbosch, R.H.; Heeres, H.J. Hydrotreatment of Fast Pyrolysis Oil Using Heterogeneous Noble-Metal Catalysts. Ind. Eng. Chem. Res. 2009, 48, 10324-10334. [CrossRef]

42. App, A.R.; Khromova, S.A.; Venderbosch, R.H.; Yakovlev, V.A.; Heeres, H.J. Catalytic hydrotreatment of fast-pyrolysis oil using non-sulfided bimetallic $\mathrm{Ni}-\mathrm{Cu}$ catalysts on a $\delta-\mathrm{Al}_{2} \mathrm{O}_{3}$ support. Appl. Catal. B 2012, 117-118, 105-117.

43. Lu, Q.; Yang, X.-L.; Zhu, X.-F. Analysis on chemical and physical properties of bio-oil pyrolyzed from rice husk. J. Anal. Appl. Pyrolysis 2008, 82, 191-198. [CrossRef]

44. Wildschut, J.; Iqbal, M.; Mahfud, F.H.; Cabrera, I.M.; Venderbosch, R.H.; Heeres, H.J. Insights in the hydrotreatment of fast pyrolysis oil using a ruthenium on carbon catalyst. Energy Environ. Sci. 2010, 3, 962-970. [CrossRef]

45. Elliott, D.C.; Hart, T.R.; Neuenschwande, G.G.; Rotness, L.J.; Olarte, M.V.; Zacher, A.H.; Solantausta, Y. Catalytic Hydroprocessing of Fast Pyrolysis Bio-oil from Pine Sawdust. Energy Fuels 2012, 26, 3891-3896. [CrossRef]

46. Elliott, D.C.; Neuenschwander, G.G. Liquid Fuels by Low-Severity Hydrotreating of Biocrude. In Developments in Thermochemical Biomass Conversion: Volume 1/Volume 2; Bridgwater, A.V., Boocock, D.G.B., Eds.; Springer: Dordrecht, The Netherlands, 1997; pp. 611-621.

47. Patel, M.; Kumar, A. Production of renewable diesel through the hydroprocessing of lignocellulosic biomass-derived bio-oil: A review. Renew. Sustain. Energy Rev. 2016, 58, 1293-1307. [CrossRef]

48. Zhang, S.; Yan, Y.; Li, T.; Ren, Z. Upgrading of liquid fuel from the pyrolysis of biomass. Bioresour. Technol. 2005, 96, 545-550. [CrossRef] [PubMed]

49. López, R.; Fernández, C.; Gómez, X.; Martínez, O.; Sánchez, M.E. Thermogravimetric analysis of lignocellulosic and microalgae biomasses and their blends during combustion. J. Therm. Anal. 2013, 114, 295-305. [CrossRef]

50. Liu, H.; Chen, Y.; Yang, H.; Gentili, F.G.; Söderlind, U.; Wang, X.; Zhang, W.; Chen, H. Hydrothermal carbonization of natural microalgae containing a high ash content. Fuel 2019, 249, 441-448. [CrossRef]

51. Plis, A.; Lasek, J.; Skawińska, A. Kinetic analysis of the combustion process of Nannochloropsis gaditana microalgae based on thermogravimetric studies. J. Anal. Appl. Pyrolysis 2017, 127, 109-119. [CrossRef]

52. Miao, X.; Wu, Q. High yield bio-oil production from fast pyrolysis by metabolic controlling of Chlorella protothecoides. J. Biotechnol. 2004, 110, 85-93. [CrossRef]

53. Jena, U.; Das, K.C. Comparative Evaluation of Thermochemical Liquefaction and Pyrolysis for Bio-Oil Production from Microalgae. Energy Fuels 2011, 25, 5472-5482. [CrossRef]

54. Guo, Q.; Wu, M.; Wang, K.; Zhang, L.; Xu, X. Catalytic Hydrodeoxygenation of Algae Bio-oil over Bimetallic Ni-Cu/ZrO 2 Catalysts. Ind. Eng. Chem. Res. 2015, 54, 890-899. [CrossRef]

55. Gruia, A. Hydrotreating. In Handbook of Petroleum Processing; Jones, D.S.J.S., Pujado, P.R., Eds.; Springer: Dordrecht, The Netherlands, 2006; pp. 321-354.

56. Jacobson, K.; Maheria, K.C.; Kumar Dalai, A. Bio-oil valorization: A review. Renew. Sustain. Energy Rev. 2013, 23, 91-106. [CrossRef]

57. Mauchausse, C.; Kural, E.; Trimm, D.L.; Cant, N.W. Optimization of tungsten-based catalysts for the hydrotreatment of coalderived liquids. Fuel 1992, 71, 203-209. [CrossRef]

58. Bulushev, D.A.; Ross, J.R.H. Catalysis for conversion of biomass to fuels via pyrolysis and gasification: A review. Catal. Today 2011, 171, 1-13. [CrossRef]

59. Masel, R.I. Principles of Adsorption and Reaction on Solid Surfaces; Wiley: New York, NY, USA; Chichester, UK, 1996.

60. Ptushinskiǔ, Y.G. Low-temperature adsorption of gases on metal surfaces (Review). Low Temp. Phys. 2004, 30, 1-26. [CrossRef] 
61. Ferrin, P.; Kandoi, S.; Nilekar, A.U.; Mavrikakis, M. Hydrogen adsorption, absorption and diffusion on and in transition metal surfaces: A DFT study. Surf. Sci. 2012, 606, 679-689. [CrossRef]

62. Elliott, D.C.; Hu, J.; Hart, T.R.; Neuenschwander, G.G. Palladium Catalyzed Hydrogenation of Bio-Oils and Organic Compounds. U.S. Patent 7,425,657, 16 September 2008.

63. Mortensen, P.M.; Grunwaldt, J.D.; Jensen, P.A.; Jensen, A.D. Screening of Catalysts for Hydrodeoxygenation of Phenol as a Model Compound for Bio-oil. ACS Catal. 2013, 3, 1774-1785. [CrossRef]

64. Ardiyanti, A.R.; Khromova, S.A.; Venderbosch, R.H.; Yakovlev, V.A.; Melián-Cabrera, I.V.; Heeres, H.J. Catalytic hydrotreatment of fast pyrolysis oil using bimetallic Ni-Cu catalysts on various supports. Appl. Catal. A 2012, 449, 121-130. [CrossRef]

65. Wei, S.; Zhao, Y.; Fan, G.; Yang, L.; Li, F. Structure-dependent selective hydrogenation of cinnamaldehyde over high-surface-area $\mathrm{CeO}_{2}-\mathrm{ZrO}_{2}$ composites supported Pt nanoparticles. Chem. Eng. J. 2017, 322, 234-245. [CrossRef]

66. Zhou, M.; Liu, P.; Wang, K.; Xu, J.; Jiang, J. Catalytic hydrogenation and one step hydrogenation-esterification to remove acetic acid for bio-oil upgrading: Model reaction study. Catal. Sci. Technol. 2016, 6, 7783-7792. [CrossRef]

67. Bergem, H.; Xu, R.; Brown, R.C.; Huber, G.W. Low temperature aqueous phase hydrogenation of the light oxygenate fraction of bio-oil over supported ruthenium catalysts. Green Chem. 2017, 19, 3252-3262. [CrossRef]

68. Yuan, Q.; Zhang, D.; van Haandel, L.; Ye, F.; Xue, T.; Hensen, E.J.M.; Guan, Y. Selective liquid phase hydrogenation of furfural to furfuryl alcohol by Ru/Zr-MOFs. J. Mol. Catal. A Chem. 2015, 406, 58-64. [CrossRef]

69. Liu, Y.; Zheng, Y.; Du, B.; Nasaruddin, R.R.; Chen, T.; Xie, J. Golden Carbon Nanotube Membrane for Continuous Flow Catalysis. Ind. Eng. Chem. Res. 2017, 56, 2999-3007. [CrossRef]

70. Fiorio, J.L.; López, N.; Rossi, L.M. Gold-Ligand-Catalyzed Selective Hydrogenation of Alkynes into cis-Alkenes via $\mathrm{H}_{2} \mathrm{Heterolytic}$ Activation by Frustrated Lewis Pairs. ACS Catal. 2017, 7, 2973-2980. [CrossRef]

71. Takeda, Y.; Tamura, M.; Nakagawa, Y.; Okumura, K.; Tomishige, K. Characterization of Re-Pd/SiO 2 Catalysts for Hydrogenation of Stearic Acid. ACS Catal. 2015, 5, 7034-7047. [CrossRef]

72. Raj, K.J.A.; Prakash, M.G.; Mahalakshmy, R.; Elangovan, T.; Viswanathan, B. Liquid phase hydrogenation of crotanaldehyde over nickel supported on titania. J. Mol. Catal. A Chem. 2013, 366, 92-98.

73. Fulajtárova, K.; Soták, T.; Hronec, M.; Vávra, I.; Dobročka, E.; Omastová, M. Aqueous phase hydrogenation of furfural to furfuryl alcohol over Pd-Cu catalysts. Appl. Catal. A 2015, 502, 78-85. [CrossRef]

74. Wang, C.; Guo, Z.; Yang, Y.; Chang, J.; Borgna, A. Hydrogenation of Furfural as Model Reaction of Bio-Oil Stabilization under Mild Conditions Using Multiwalled Carbon Nanotube (MWNT)-Supported Pt Catalysts. Ind. Eng. Chem. Res. 2014, 53, 11284-11291. [CrossRef]

75. Ota, N.; Tamura, M.; Nakagawa, Y.; Okumura, K.; Tomishige, K. Performance, Structure, and Mechanism of ReOx-Pd/CeO 2 Catalyst for Simultaneous Removal of Vicinal OH Groups with $\mathrm{H}_{2}$. ACS Catal. 2016, 6, 3213-3226. [CrossRef]

76. Nakagawa, Y.; Tamura, R.; Tamura, M.; Tomishige, K. Combination of supported bimetallic rhodium-molybdenum catalyst and cerium oxide for hydrogenation of amide. Sci. Technol. Adv. Mater. 2015, 16, 014901. [CrossRef]

77. Liao, X.; Zhang, Y.; Guo, J.; Zhao, L.; Hill, M.; Jiang, Z.; Zhao, Y. The Catalytic Hydrogenation of Maleic Anhydride on $\mathrm{CeO}_{2}-\delta$-Supported Transition Metal Catalysts. Catalysts 2017, 7, 272. [CrossRef]

78. Elliott, D.C. Historical developments in hydroprocessing bio-oils. Energy Fuels 2007, 21, 1792-1815. [CrossRef]

79. Laurent, E.; Delmon, B. Study of the hydrodeoxygenation of carbonyl, car $\square$ ylic and guaiacyl groups over sulfided $\mathrm{CoMo} / \gamma-\mathrm{Al}_{2} \mathrm{O}_{3}$ and $\mathrm{NiMo} / \gamma-\mathrm{Al}_{2} \mathrm{O}_{3}$ catalysts: I. Catalytic reaction schemes. Appl. Catal. A 1994, 109, 77-96. [CrossRef]

80. Bienholz, A.; Schwab, F.; Claus, P. Hydrogenolysis of glycerol over a highly active $\mathrm{CuO} / \mathrm{ZnO}$ catalyst prepared by an oxalate gel method: Influence of solvent and reaction temperature on catalyst deactivation. Green Chem. 2010, 12, 290-295. [CrossRef]

81. Liu, H.; Liang, S.; Jiang, T.; Han, B.; Zhou, Y. Hydrogenolysis of Glycerol to 1,2-Propanediol over Ru-Cu Bimetals Supported on Different Supports. CLEAN Soil Air Water 2012, 40, 318-324. [CrossRef]

82. de Miguel Mercader, F.; Groeneveld, M.J.; Kersten, S.R.A.; Geantet, C.; Toussaint, G.; Way, N.W.J.; Schaverien, C.J.; Hogendoorn, K.J.A. Hydrodeoxygenation of pyrolysis oil fractions: Process understanding and quality assessment through co-processing in refinery units. Energy Environ. Sci. 2011, 4, 985-997. [CrossRef]

83. Prasomsri, T.; Shetty, M.; Murugappan, K.; Román-Leshkov, Y. Insights into the catalytic activity and surface modification of $\mathrm{MoO}_{3}$ during the hydrodeoxygenation of lignin-derived model compounds into aromatic hydrocarbons under low hydrogen pressures. Energy Environ. Sci. 2014, 7, 2660-2669. [CrossRef]

84. Bagnato, G.; Signoretto, M.; Pizzolitto, C.; Menegazzo, F.; Xi, X.; ten Brink, G.H.; Kooi, B.J.; Heeres, H.J.; Sanna, A. Hydrogenation of Biobased Aldehydes to Monoalcohols Using Bimetallic Catalysts. ACS Sustain. Chem. Eng. 2020, 8, 11994-12004. [CrossRef]

85. Sanna, A.; Vispute, T.P.; Huber, G.W. Hydrodeoxygenation of the aqueous fraction of bio-oil with Ru/C and Pt/C catalysts. Appl. Catal. B 2015, 165, 446-456. [CrossRef]

86. Oasmaa, A.; Kuoppala, E.; Solantausta, Y. Fast Pyrolysis of Forestry Residue. 2. Physicochemical Composition of Product Liquid. Energy Fuels 2003, 17, 433-443. [CrossRef]

87. Oasmaa, A.; Kuoppala, E.; Gust, S.; Solantausta, Y. Fast Pyrolysis of Forestry Residue. 1. Effect of Extractives on Phase Separation of Pyrolysis Liquids. Energy Fuels 2003, 17, 1-12. [CrossRef]

88. Adjaye, J.D.; Bakhshi, N.N. Production of hydrocarbons by catalytic upgrading of a fast pyrolysis bio-oil. Part II: Comparative catalyst performance and reaction pathways. Fuel Process. Technol. 1995, 45, 185-202. [CrossRef] 
89. De la Puente, G.; Gil, A.; Pis, J.J.; Grange, P. Effects of Support Surface Chemistry in Hydrodeoxygenation Reactions over CoMo/Activated Carbon Sulfided Catalysts. Langmuir 1999, 15, 5800-5806. [CrossRef]

90. Gutierrez, A.; Kaila, R.K.; Honkela, M.L.; Slioor, R.; Krause, A.O.I. Hydrodeoxygenation of guaiacol on noble metal catalysts. Catal. Today 2009, 147, 239-246. [CrossRef]

91. Bui, V.N.; Laurenti, D.; Afanasiev, P.; Geantet, C. Hydrodeoxygenation of guaiacol with CoMo catalysts. Part I: Promoting effect of cobalt on HDO selectivity and activity. Appl. Catal. B 2011, 101, 239-245. [CrossRef]

92. Centeno, A.; Laurent, E.; Delmon, B. Influence of the Support of CoMo Sulfide Catalysts and of the Addition of Potassium and Platinum on the Catalytic Performances for the Hydrodeoxygenation of Carbonyl, Carboxyl, and Guaiacol-Type Molecules. J. Catal. 1995, 154, 288-298. [CrossRef]

93. Ferrari, M.; Delmon, B.; Grange, P. Influence of the active phase loading in carbon supported molybdenum-cobalt catalysts for hydrodeoxygenation reactions. Microporous Mesoporous Mater. 2002, 56, 279-290. [CrossRef]

94. Bindwal, A.B.; Bari, A.H.; Vaidya, P.D. Kinetics of low temperature aqueous-phase hydrogenation of model bio-oil compounds. Chem. Eng. J. 2012, 207-208, 725-733. [CrossRef]

95. Bindwal, A.B.; Vaidya, P.D. Kinetics of Aqueous-Phase Hydrogenation of Levoglucosan over Ru/C Catalyst. Ind. Eng. Chem. Res. 2013, 52, 17781-17789. [CrossRef]

96. Zhang, S.; Yan, Y.; Li, T.; Ren, Z. Lumping Kinetic Model for Hydrotreating of Bio-oil from the Fast Pyrolysis of Biomass. Energy Sources Part A 2009, 31, 639-645. [CrossRef]

97. Zhang, S.-P. Study of Hydrodeoxygenation of Bio-Oil from the Fast Pyrolysis of Biomass. Energy Sources 2003, $25,57-65$.

98. Sheu, Y.-H.E.; Anthony, R.G.; Soltes, E.J. Kinetic studies of upgrading pine pyrolytic oil by hydrotreatment. Fuel Process. Technol. 1988, 19, 31-50. [CrossRef]

99. Bagnato, G.; Iulianelli, A.; Sanna, A.; Basile, A. Glycerol Production and Transformation: A Critical Review with Particular Emphasis on Glycerol Reforming Reaction for Producing Hydrogen in Conventional and Membrane Reactors. Membranes 2017, 7, 17. [CrossRef] [PubMed]

100. Iulianelli, A.; Longo, T.; Basile, A. Methanol steam reforming reaction in a $\mathrm{Pd}-\mathrm{Ag}$ membrane reactor for CO-free hydrogen production. Int. J. Hydrogen Energy 2008, 33, 5583-5588. [CrossRef]

101. Iulianelli, A.; Longo, T.; Basile, A. CO-free hydrogen production by steam reforming of acetic acid carried out in a Pd-Ag membrane reactor: The effect of co-current and counter-current mode. Int. J. Hydrogen Energy 2008, 33, 4091-4096. [CrossRef]

102. Liu, M.; Zhu, X.; Chen, R.; Liao, Q.; Feng, H.; Li, L. Catalytic membrane microreactor with $\mathrm{Pd} / \gamma-\mathrm{Al}_{2} \mathrm{O}_{3} \mathrm{coated} \mathrm{PDMS}$ film modified by dopamine for hydrogenation of nitrobenzene. Chem. Eng. J. 2016, 301, 35-41. [CrossRef]

103. Liu, C.; Xu, Y.; Liao, S.; Yu, D. Mono- and bimetallic catalytic hollow- fiber reactors for the selective hydrogenation of butadiene in 1-butene. Appl. Catal. A Gen. 1998, 172, 23-29. [CrossRef]

104. Stanford, J.P.; Soto, M.C.; Pfromm, P.H.; Rezac, M.E. Aqueous phase hydrogenation of levulinic acid using a porous catalytic membrane reactor. Catal. Today 2016, 268, 19-28. [CrossRef]

105. Bagnato, G.; Figoli, A.; Ursino, C.; Galiano, F.; Sanna, A. A novel Ru-polyethersulfone (PES) catalytic membrane for highly efficient and selective hydrogenation of furfural to furfuryl alcohol. J. Mater. Chem. A 2018, 6, 4955-4965. [CrossRef]

106. Liguori, F.; Barbaro, P.; Giordano, C.; Sawa, H. Partial hydrogenation reactions over Pd-containing hybrid inorganic/polymeric catalytic membranes. Appl. Catal. A Gen. 2013, 459, 81-88. [CrossRef]

107. Aran, H.C.; Klooster, H.; Jani, J.M.; Wessling, M.; Lefferts, L.; Lammertink, R.G.H. Influence of geometrical and operational parameters on the performance of porous catalytic membrane reactors. Chem. Eng. J. 2012, 207-208, 814-821. [CrossRef]

108. Bottino, A.; Capannelli, G.; Comite, A.; Del Borghi, A.; Di Felice, R. Catalytic ceramic membrane in a three-phase reactor for the competitive hydrogenation-isomerisation of methylenecyclohexane. Sep. Purif. Technol. 2004, 34, 239-245. [CrossRef]

109. Bottino, A.; Capannelli, G.; Comite, A.; Di Felice, R. Polymeric and ceramic membranes in three-phase catalytic membrane reactors for the hydrogenation of methylenecyclohexane. Desalination 2002, 144, 411-416. [CrossRef]

110. Bengtson, G.; Fritsch, D. Catalytic membrane reactor for the selective hydrogenation of edible oil: Platinum versus palladium catalyst. Desalination 2006, 200, 666-667. [CrossRef]

111. Liguori, F.; Barbaro, P.; Sawa, H. Continuous flow hydrogenation reactions by Pd catalysts onto hybrid $\mathrm{ZrO}_{2} / \mathrm{PVA}$ materials. Appl. Catal. A Gen. 2014, 488, 58-65. [CrossRef] 